\title{
25 Research Soure \\ Development of Analytical Seismic Fragility Functions For The Common Buildings In Iran
}

\section{Zarrin Karimzadeh ( $\nabla$ zkarimzadeh73@gmail.com )}

IIEES: International Institute of Earthquake Engineering and Seismology https://orcid.org/0000-0003-3652-9902

Mohsen Ghafory-Ashtiany

International Institute of Earthquake Engineering and Seismology

Afshin Kalantari

IIEES: International Institute of Earthquake Engineering and Seismology

Sahar Shokuhirad

IIEES: International Institute of Earthquake Engineering and Seismology

\section{Research Article}

Keywords: Earthquake, Iran, Iranian buildings, Taxonomy, Fragility functions, Seismic risk

Posted Date: December 17th, 2021

DOl: https://doi.org/10.21203/rs.3.rs-1164402/v1

License: (9) (i) This work is licensed under a Creative Commons Attribution 4.0 International License. Read Full License 


\section{Abstract}

One of the main components for the development of regional seismic risk models is the fragility functions for common building types. Due to the differences between the national design codes, construction practices, and construction materials, it is necessary to develop specific fragility functions for the common building types which are constructed in each region. One of the existing challenges is the lack of classified, reliable, and cogent local seismic fragility functions for common buildings in Iran. For this reason, the present study is devoted to filling this essential gap. Therefore, at the first step, a comprehensive study was performed on the existing building types in the country. Finally, the Iranian common buildings are classified into 35 categories regarding material, lateral-loadresisting system, age, height, and code level. Also, by conducting comprehensive studies on all previously performed researches in the country, structural and dynamic parameters have been collected for buildings in each class. This information was used to compute a large set of backbone curves for Iranian buildings taxonomy. In the next steps, a large set of ground motion records were selected. Then non-linear time-history analyses were performed on the generic backbone curve for each type of building, and the structural responses were used to derive fragility functions for building classes. Then nearly three hundred appropriate fragility functions were generated for Iranian common buildings considering both record-to-record and building-to-building response variability using cloud analysis. Based on the existing empirical data from past earthquakes in the country, the validation of the resulting fragility functions was carried out. The resulted fragility functions can be utilized in seismic risk assessment studies in the country.

\section{Introduction}

Earthquake, as one of the most important natural disasters in Iran, has caused extensive economic and human losses, mainly due to the destruction of vulnerable buildings (Tavakoli and Ghafory-Ashtiany 1999). The most recent earthquake with Mw 7.3 occurred on November 12, 2017, in Sarpol-e Zahab city in Kermanshah province, which left approximately 600 fatalities (Zare et al. 2017). For reliable assessment of seismic vulnerability and risk of buildings, requires the development of reliable fragility functions of the common building types constructed in Iran.

The development of appropriate/reliable fragility functions has been the aim of various studies. In these studies, fragility functions have been developed based on different methods, which can be classified into three main groups: empirical methods, expert opinion-based, analytical methods. Empirical fragility functions are developed based on a statistical analysis of observed damage from past earthquakes, such as from data collected by post-earthquake surveys (Colombi et al. 2008; Sabetta et al. 1998). Expert opinion-based fragility functions are proposed based on the judgment and information of experts (ATC-13 1985; Jaiswal et al. 2012). Analytical fragility functions are developed starting from the statistical elaboration of damage distributions that are simulated from analyses of structural models under increasing earthquake intensity (HAZUS 1999; Ibarra and Krawinkler 2005; Rossetto and Elnashai 2005; Nasserasadi et al. 2008; Samadian et al. 2019). Despite the existence of notable studies that have been conducted to develop fragility functions for different buildings in the country, due to the differences between the development methods, type of buildings, type of intensity measures, definition of damage states, the results of these studies are widely dispersed. Thus, it is necessary to develop uniform fragility functions for the common building types which are constructed in Iran.

This paper focused on a comprehensive study of the existing building types in the country to identify the common building types and building taxonomy of Iran based on the material, structural system, code-conformance, and 
height; which resulted in 14 major types of buildings. Then, a comprehensive review has been performed to determine the principal structural and dynamic characteristics of the 14 types of Iranian buildings to derive their equivalent Single-Degree-Of-Freedom (SDOF) models. For seismic demand, the Ghafory-Ashtiany et al. (2021) method was used to define representative Strong Ground Motion Records (SGMRs) from a large database of approximately 4000 records. Martins and Silva (2020) analytical procedure was used to developing fragility functions that consider the building-to-building variability, record-to-record variability, and uncertainty in the definition of the damage criterion using a low computational effort. All of the calculations were performed using the Vulnerability Modellers Toolkit (VMTK) (Martins et al. 2021). This study has developed more than 300 fragility functions for 14 common buildings in Iran, which have been considered in three code levels. The outcomes of this study can utilize in regional and national earthquake risk analyses.

\section{A Brief Review Of The Current State Of Studies On The Development Of Fragility Functions For Buildings}

This section provides a brief overview of the most important studies performed for the development of fragility functions, especially in Iran. HAZUS (HAZUS 1999) is one of the well-known projects on the development of seismic fragility functions based on structural modeling and simulations, which has been done by a collaboration of the Federal Emergency Management Agency (FEMA) and the National Institute of Building Sciences (NIBS). The HAZUS instruction is designed to produce loss estimates for regional and local governments in planning for earthquake risk mitigation, emergency preparedness, response, and recovery specifically for the United States. In 2003 Risk-UE project (Mouroux and Le Brun 2006) was done in Europe to implement risk management and risk mitigation programs. The RISK-UE WP4 group was identified to develop fragility and vulnerability functions for residential buildings using empirical methods based on post-earthquake damage assessment data. SYNER-G was a European research project, which initiated in 2009 (Pitilakis et al. 2014). The main target of this project was to provide a framework for seismic risk assessment of structures in urban and rural areas. SYNER-G project aimed to identify the main typologies of building in Europe and collect existing fragility functions. The Global Earthquake Model (GEM) initiated numerous projects related to the assessment of physical earthquake risk estimation. Parts of these projects were assigned to collecting a large number of fragility and vulnerability functions (Rossetto et al. 2014; D’Ayala et al. 2015). Villar-Vega et al. (2017) focused broadly on the South American building stock, and developed fragility functions for residential building stock, using single-degree-of-freedom (SDOF) oscillators to model the response of the buildings. This study has utilized the GEM's Risk Modellers Toolkit (RMTK) (Silva et al. 2017) for the development of fragility functions. Martins and Silva (2020) also have been developed a fragility and vulnerability model for global seismic risk assessment using the RMTK, which supported by the GEM Foundation (Silva et al. 2017).

During the past years, several studies have been performed to assess seismic fragility and vulnerability functions for Iranian buildings. The first study on seismic fragility curves in Iran was carried out by Tavakoli and Favakoli (1993) based on the Manjil-Rudbar earthquake data in 1990. This study presented empirical fragility functions for residential buildings regardless of the year of construction, seismic code, and building types. In another study, part of the GEM project was dedicated to the Middle East region, which was called the EMME project. The main part of the EMME project, which was relevant to seismic risk assessment in the region, was assigned to WP4 (Mansouri and Amini-Hosseini 2013). The first important result of this project was determining residential building taxonomy for Iran based on the national census database. The other important result of this project was the derivation of appropriate vulnerability functions to estimate the building damage and the associated casualties. 
Omidvar et al. (2012) have presented the empirical fragility curves for engineered steel, and RC structures in Iran based on the observed damage from previous earthquakes that have occurred in Iran, mainly the 1990 Manjil and 2003 Bam earthquakes. Sadeghi et al. (2015) developed a set of vulnerability curves for the 42 Iranian building types by combining the existing fragility/vulnerability curves in Iran and other countries with similar seismicity and construction practices. Kazemi et al. (2017) developed fragility curves for steel braced frame structures using new spectral shape indicators and a weighted damage index in the city of Mashhad, Iran. Motamed et al. (2018) defined 23 building classes based on the construction material, building height, lateral load resisting system, and year of construction. The output of this study was the fragility functions for some of the building classes in Iran in order to utilize for the development of a probabilistic earthquake loss model for the country. Fallah Tafti et al. (2020) also categorized all buildings in Iran into 19 classes in terms of building structure types, building quality, and building height. In this study, 19 sets of expert judgment-based fragility functions were developed for the different types of common buildings in Iran. These fragility functions were developed using existing empirical fragility functions in Iran and those proposed for similar types of buildings in other countries. Kohrangi et al. (2021) classified the buildings into 27 types based on age, height, material, and lateral-load-resisting system. This study developed a seismic risk model for the city of Isfahan using the exposure, fragility, and vulnerability models for the residential, mixed residential/commercial, and public building stock. Biglari et al. (2021) investigated the damaged database of engineered residential steel and RC buildings after Mw7.3 2017 earthquake. This study presented the empirical fragility curves for engineered steel and RC structures.

\section{Buildings Taxonomy In Iran}

\subsection{Development of a taxonomy for Iranian buidings}

A necessary prerequisite for the vulnerability assessment of buildings is identifying the common building types in the country, which should be classified based on important parameters such as the construction material, the lateral load resisting system, design quality, and height. To develop and classify the comprehensive inventory of the most common building types in Iran, an extensive study has been performed on the existing building taxonomies worldwide, in order to come up with an updated taxonomy for Iran with the consideration of the most important parameters.

HAZUS (1999) has classified buildings based on their occupancy and their structural system, height, and design levels into 36 common building types in the United States. In the RISK-UE project (Mouroux and Le Brun 2006), the building taxonomy includes 23 main groups dominantly comprised of masonry and RC building types, which have been classified according to the types of structural systems, materials used for construction, height, and design quality. The WHE-PAGER project (Jaiswal et al. 2010) developed a taxonomy based on the collection and classification of commonly observed buildings in 30 countries from all over the world, such as Iran (available at www.world-housing.net). The Global Earthquake Model (Brzev et al. 2013) developed a comprehensive taxonomy based on the material of construction, lateral load resisting system, roof, floor, height, date of construction, structural irregularity, and occupancy.

Also, similar studies have been conducted in Iran, which have been reviewed in the previous section. In addition to the mentioned studies, the Statistical Center of Iran ( SCI 2018) Classified the existing buildings into three categories of steel structure, reinforced concrete, and others based on their structure types. These categories are not exhaustive and do not include all common buildings in Iran. Therefore, with respect to the above description of several studies that were relevant for the development of a building taxonomy, in the current study, some 
parameters have been selected in order to classify existing buildings in urban and rural areas of Iran. These parameters consist of construction material, lateral load resisting system, code level (which is defined based on the integration of the seismicity level and the year of construction), and height. The procedure and the parameters that are reflected in the development of the buildings taxonomy are discussed in this section.

\subsection{Building classification based on the construction material and the lateral load resisting system}

In this section, based on previous researches and the experts' opinion, common building types in Iran are classified into two main categories: engineered buildings and non-engineered buildings. Engineered buildings, include steel moment bare frame, steel moment infill frame, steel braced frame, steel braced frame with the concrete shear wall, Steel frames with dual system, Steel braced frames with Khorjini connections, RC moment bare frame, RC moment infill frame, RC frames with the shear wall, RC tunnel-form, and (2) non-engineered buildings include all types of masonry buildings, adobe, and wooden buildings. Iranian buildings classification based on construction material and load resisting system are presented in Table 1.

\subsection{Buildings Classification based on code level}

In this study, code level is defined based on the year of construction and the seismicity levels of the region, which the buildings are designed. The existing Iranian buildings were mostly designed based on the various version of the Iranian standard for seismic design of buildings ( Standard No. 2800, ICSRDB 2014, http://www.std2800.ir) and the Iranian National Buildings Code parts 8, 9, and 10 (INBC Part 8 2013; INBC Part 9 2013; INBC Part10 2013, https://inbr.ir). Therefore the existing buildings are categorized into four groups based on the different editions of Iranian building codes, as shown in Table 2.

The STD-2800 divided Iran into four seismic hazard zones with the Design-Based Earthquake (DBE) values of $0.35 \mathrm{~g}$ (very high), $0.30 \mathrm{~g}$ (high), $0.25 \mathrm{~g}$ (moderate), $0.20 \mathrm{~g}$ (low)]. Due to the low differences in the reference design PGA, only two seismic levels were considered in this study. Level 1 is equivalent to low and moderate seismic zones, and level 2 is equivalent to high and very high seismic zones of STD-2800. Combining the seismic levels of the STD-2800 and the year of construction, common buildings in Iran are divided into four code levels: Pre-Code, Low-code, Moderate-code, and High-code. The classification of Iranian buildings based on the code level is presented in Fig. 1. It should be noted that for the RC, steel, and confined masonry buildings, the difference between the Pre-Code and Low-Code levels is not recognizable, so these two code levels have been merged, and three code levels consist of Low-Code, Moderate-Code, and High-Code have been considered for these building classes. For Unreinforced Masonry, Wood, and Adobe buildings, these classifications based on code-level do not really exist, so only one level has been considered for them.

\subsection{Buildings classification based on height}

Iranian building taxonomy, as shown in Table 3, has been defined based on the experts' opinion of the IIEES Structural research center, and the statistical survey on existing buildings in urban and rural regions of Iran. The height has been divided into three categories considering the different heights of buildings: low-rise ( 1 to 3 stories buildings), mid-rise (4 to 7 stories buildings), and high-rise (over 8 stories buildings). In this study, a Model Building Type (MBT) has been considered for each building class, as shown in the last column of Table 3 , in order to present the results only for MBTs. Also, Table 3 was described the related IDs used for displaying results for each building type. 


\section{Fragility Analyses}

Many studies using different methods have been accomplished on developing seismic fragility functions. The Global Earthquake Model (GEM) conducted a guideline, which has been presented the most advanced methods for the derivation of robust fragility functions for the building typologies (D'Ayala et al. 2015). Similar researches were also conducted to describe existing methods for developing fragility curves and discussed the existing challenges in each of these methods (Calvi et al. 2006b; Silva et al. 2019). Utilizing these methodologies depends on the availability, quality, and level of precision of input data.

In this study, the development of the fragility functions follows the analytical procedure proposed by Martins and Silva (2020). In this procedure, inputs are defined in terms of a set of ground motion records and equivalents SDOF systems that are illustrative of the buildings within each specific class. Structural responses have been obtained using NonLinear Time-History Analysis (NLTHA) of equivalent SDOF systems with the consideration of record-torecord uncertainty and building-to-building variability. Then the fragility functions have been developed using the cloud analysis approach proposed by (Jalayer et al. 2015), considering the uncertainty in the definition of the damage criterion. All of the calculations related to the nonlinear response of the SDOF oscillators, and the derivation of fragility functions were performed using the VMTK (Martins et al. 2021), an open-source software for deriving fragility and vulnerability functions. One of the advantages of this procedure is utilizing the simplified SDOF models, which their response is not computationally heavy and time-consuming. All of the required inputs and steps for the development of the fragility functions are defined separately and completely in the following sub-sections. Also, each of the above-mentioned steps is explained in the flow diagram presented in Fig. 2.

\subsection{Definition of structural and dynamic parameters for Iranian buildings}

To define the proper structural parameters required for the capacity curves of each building class, a review on the previous research conducted by Calvi (1999), Borzi et al. (2008a, b), Ahmad et al. (2010), Villar-Vega et al. (2017), and Martins and Silva (2020) has been made. The selected parameters have been shown in Table 4. In this study, initially, to define the structural and dynamic parameters for Iranian buildings taxonomy, the backbone curves from the existing studies in Iran were collected. For some of the building types where not sufficient data were available in Iran, the parameters were chosen based on the existing studies for similar buildings to Iran. Finally, approximately 100 backbone curves were collected. Considering the expert's opinion about the level of appropriateness and accuracy of different researches, which collected in this survey, a weight factor was assigned for each curve. Then, the existing parameters at each category were combined, based on their weights obtained from engineering judgment, to determine the final parameters for each class of building. The considered structural and dynamic parameters for Iranian buildings taxonomy and the list of related references, which have been utilized to define these parameters, are demonstrated in Table 4.

\subsection{Nonlinear Equivalent SDOF systems for the buildings taxonomy}

One generic capacity curve per building class in Acceleration Displacement Response Spectrum (ADRS) format (spectral acceleration versus spectral displacement) is defined based on the parameters determined in the previous section. The elastic-perfectly plastic behavior of each SDOF oscillator are computed based on the related backbone curve in ADRS format using the following equations : 
$\mathrm{S}_{\mathrm{d}}=\frac{N_{\text {storey }} * H_{\text {storey }} * \theta_{\text {global }}}{\Gamma}, \mathrm{S}_{\mathrm{ay}}=\mathrm{S}_{\mathrm{dy}} *\left(\frac{2 * \Pi}{T y}\right)^{2}$, Sau $=$ Say $(1)$

Where, $\mathrm{S}_{\mathrm{d}}=$ spectral displacement at the yielding or ultimate points, depending on the global drift $\theta_{\text {global. }} . N_{\text {storey }}=$ the number of storeys, $H_{\text {storey }}=$ the inter-storey height, $\Gamma=$ first mode of vibration participation factor; $T y$ stands for the period of vibration at the yielding point; and $S_{a y}$, and $S_{a u}$ represents the spectral acceleration at the yielding and ultimate points, respectively. To characterize the seismic response and the performance of each building type, a generic equivalent SDOF system with a backbone curve and a hysteresis behavior are defined. For this purpose, recommendations by Dolšek and Fajfar (2008), Riahi et al. (2009), Bal et al. (2010), Silva et al. (2014b), Villar-Vega et al. (2017), Martins and Silva (2020), and also the experts' opinions have been used. The "Bilinear idealization shape" was supported to express the backbone curve for the steel and timber structures, which define based on 3 pairs of points, as illustrated in Fig. 3a. As defined in Fig. 3a, the first point of the backbone curve was equal to zero. The last two points of the backbone curve were calculated according to the yield displacement $\left(S_{\text {dy }}\right)$, the ultimate displacement $\left(\mathrm{S}_{\mathrm{du}}\right)$, and the corresponding spectral accelerations $\left(\mathrm{S}_{\mathrm{ay}}, \mathrm{S}_{\mathrm{au}}\right)$.

The backbone curves with three branches can also be found in the literature, depending on the characteristics of the building type. The "Tri-linear idealization shape" was supported to express the backbone curve for the RC, confined and unreinforced masonry, and adobe structures which no notable decrease in the strength and stiffness anticipated. Tri-linear backbone curves are defined based on 4 pairs of points as described in Fig. $3 \mathrm{~b}$. In these curves, the initial branch has been defined with two different slopes. The first is proportional to the elastic period $\left(T_{1}\right)$, and the second is proportional to the yielding period $\left(T_{y}\right)$. In this case, the value of $T_{y}$ is considered equal to 1.5 times the value of $T_{1}$ (Calvi et al. 2006a; Crowley and Pinho 2006; Martins and Silva 2020). The displacements for these building classes were defined based on the yield and ultimate displacements $\left(S_{d y}, S_{d u}\right)$.

Martins and Silva (2020) recommended the "Quadrilinear idealization shape" to represent the backbone curve for the infilled reinforced concrete structures that anticipated a notable decrease in the strength and stiffness due to the structural damage of the masonry walls, as shown in Fig. 3c. These curves are defined through the yield $\left(S_{d y}\right)$ and ultimate $\left(S_{d u}\right)$ displacements and the elastic $\left(T_{1}\right)$ and yield $\left(T_{y}\right)$ periods. The displacements for the first two points were defined similarly to the tri-linear backbone curve. The corresponding spectral acceleration for the first two points was considered equal to 50 percent of the spectral acceleration at the yielding point $\left(0.5 \mathrm{~S}_{\text {ay }}\right)$ and the spectral acceleration at the yielding point $\left(S_{a y}\right)$, respectively. The third point corresponds to the yielding point of the $\mathrm{RC}$ frame alone, without any contribution to the infills (i.e., bare frame). In the end, the last point is defined based on the ultimate displacement of the system.

\subsection{Selection of Ground Motion Records}

Generally, the GM selection methods that are utilized for seismic vulnerability assessment of structures can be divided into two main categories. In the first method, a more general approach is used to select generic sets of ground motions in order to investigate the structure's responses. These sets of ground motions are popular because they allow users to obtain ground motions with a minimum amount of effort. These sets of ground motion records are appropriate for use in vulnerability assessment because they make the assessment procedure much simpler. In the second method, the ground motion records select to represent the seismic hazard in the specific site. These sets of ground motions are viewed as the best estimate of what future ground motions are at the specific site of interest (Baker et al. 2011; Ghafory-Ashtiany et al. 2011; Jayaram et al. 2011; Baker 2011; Mousavi et al. 2011; Azarbakht et al. 2012; Ghafory-Ashtiany et al. 2014; Silva et al. 2019; Mohandesi et al. 2019). 
This study aims to develop a national database of fragility functions to be used in large-scale risk assessment all over the country. So, the records have been selected utilizing the first aforementioned method considering the tectonic environment and seismicity of Iran. So, a large database of ground motions has been specially selected from the IIEES SGMR Toolbox (Ghafory-Ashtiany et al. 2021) to be used to perform NLTHAs on the idealized SDOF systems. Using this large database of ground motion records helps to consider the record-to-record variability, which is one of the significant sources of uncertainty in fragility assessment. IIEES SGMR toolbox includes records in the period of 1975-2017 as shown in Fig. 4a. Most of the earthquakes and recorded data belong to the years 2005, $2006,2012,2013$, and 2017. This main dataset is composed of 3521 time series out of 1025 earthquakes recorded at 594 different stations, with moment magnitudes varying from 2.0 to 7.7 and Joyner-Boore distances within 220 $\mathrm{km}$. Fig. 4b demonstrates the location of considered stations and the locations of the selected earthquakes in Iran. Most of the data (about 89\%) are relative to distances shorter than $60 \mathrm{~km}$, and most of the stations are Vs30 larger than $375 \mathrm{~m} / \mathrm{s}$ (using the Vs30 measured or estimated by the empirical method).

Finally, In this study, PGA and spectral acceleration (SA) at three periods of vibration (0.3 s,0.6s, and $1.0 \mathrm{~s})$ were selected as the Intensity Measure (IM) for the fragility assessment. These Intensity Measure Types (IMT) were utilized during the record selection procedure in order to have four sets of records close to the dynamic properties of the building types, which increase the accuracy and efficiency in response prediction. Ten levels of ground shaking were defined for each intensity measure type between $0.1 \mathrm{~g}$ and $2.0 \mathrm{~g}$. Then For each Intensity Measure Level (IML), 30 records were randomly selected at each level of ground shaking from the initial catalog. In case that 30 records have not existed for a particular IML (which generally occurs in high IML), the records were scaled up to a maximum of 2.0 times (Watson-Lamprey and Abrahamson 2006) in order to lead to the minimum number of ground motion records. Fig. 5 illustrates the response spectra of a set of 300 ground motion records corresponding to each of four selected IM types.

\subsection{Definition of the Damage Criterion}

There are several classifications of damage criteria to describe building damage from different perspectives (e.g. ATC-13 1985; HAZUS 1999). In this study, four damage criteria are considered, corresponding to slight, moderate, extensive, and complete damage levels following the recommendations of previous studies (Lagomarsino and Giovinazzi 2006; Silva et al. 2014a; Villar-Vega et al. 2017; Martins and Silva 2020). These Limit states are defined based on the yielding and ultimate displacement of each system. Herein, the limit states corresponding to defined damage criteria for this study have been described in the following list:

I. Slight Damage (LS1), corresponds to 75 percentile of spectral displacement at the yielding point;

II. Moderate Damage (LS2), defined at spectral values of $0.5 \times \mathrm{Sd}_{\mathrm{y}}+0.33 \times \mathrm{Sd}_{\mathrm{u}}$;

III. Extensive Damage (LS3), defined at spectral values of $0.25 \times \mathrm{Sd}_{\mathrm{y}}+0.67 \times \mathrm{Sd}_{\mathrm{u}}$;

IV. complete damage (LS4), equal to spectral displacement at the ultimate point;

The Engineering Demand Parameter (EDP) for each damage criteria was fitted with a lognormal distribution for this study. The statistical parameters assigned to this lognormal distribution were a mean equal to the threshold presented above, and a coefficient of variation of 45\% (Borzi et al. 2008b, a; Martins and Silva 2020).

\subsection{Fragility functions assessment methodology}

As briefly described earlier, all calculations relevant to the development of fragility functions (e.g. derivation of the backbone curves, structural response) are performed by the VMTK software (Martins et al. 2021). The VMTK is an open-source software developed with the Python programming language, and integrated with the open-source finite 
element model software OpenSEES (McKenna et al. 2000), in order to compute the nonlinear response of the SDOF oscillators. The VMTK's source code is freely available through a public GitHub repository

(https://github.com/GEMScienceTools/VMTK-Vulnerability-Modellers-ToolKit). This software consists of six modules that users can perform all the steps of developing fragility and vulnerability curves from the record selection to the validation and verification of the results utilizing the VMTK. These modules are:

i. Selection of appropriate ground motion records In order to take into consideration the record-to-record uncertainty,

ii. Definition of structural capacity that is defined by bilinear, trilinear or quadrilinear backbone curves,

iii. Structural response module,

iv. Fragility function module,

v. Derivation of vulnerability functions,

vi. Validation of the results,

In this section, an overview of modules (iii) and (iv) are given. Module (iii) estimates structural response by utilizing Nonlinear Dynamic Analyses (NDA) on SDOF oscillators using OpenSEES software. The hysteresis model of each SDOF was defined according to the relevant backbone curve and using the uniaxial material Pinching 4 considering structural degradation in three stages: 1 . unloading stiffness degradation, 2. reloading stiffness degradation, and 3. strength degradation. The default degradation implementation, which was adapted from simpleSDOF4.tcl by Vamvatsikos (2011), has been utilized using the energy option of Pinching4 (The reader is encouraged to study Martins et al. (2021) for more information about this process). Also, a damping of $7.5 \%$ has been considered in the analysis. Each SDOF system (one per building class) was tested against a set of ground motion records, leading to 300 dynamic analyses. After performing the structural analyses, the maximum spectral displacement or the maximum spectral acceleration was computed for each SDOF as the EDPs.

In module (iv) the development of the fragility functions is performed based on the cloud analysis, presented by Jalayer et al. (2015). Cloud analysis is based on simple regression between the structural response and the seismic intensity measure for a suit set of ground motion records in the logarithmic space. With a proper record selection, the cloud method manages to consider both record-to-record variability and building-to-building variability, which are two main sources of uncertainty related to the fragility analysis. Fig. 6a shows a distribution of EDPs versus Intensity Measure (IM) levels for a 5-storey steel moment frame building. So, the expected value of the EDP for an intensity measure $\left(E\left[\ln \left(E D P_{i}\right)\right]\right)$ is modeled by a linear regression equation with parameters a and $b$, while the standard error of the regression estimates the standard deviation or dispersion due to the record-to-record variability $\left(\sigma_{\text {rec_to_rec }}\right)$; Eq. $(2)$. In this equation, $\left(E\left[\ln \left(E D P_{\mathrm{i}}\right)\right]\right)$ stands for the expected value of the EDP given an IM, $\sigma_{\text {rec_to_rec }}$ is the record-to-record variability, $b$ and a are the regression parameters, $n$ is the number of records, and EDP $\mathrm{i}_{\mathrm{i}}$ corresponds to the i-EDP value obtained from the non-linear analysis for the corresponding $\mathrm{IM}_{\mathrm{i}}$.

$$
\begin{gathered}
E[\ln E D P]=\ln a+b \ln I M \\
\sigma_{r e c-t o-r e c}=\sqrt{\frac{\sum_{i=1}^{n}\left(\ln E D P_{i}-E[\ln E D P]\right)^{2}}{n-2}}
\end{gathered}
$$

2

From the two models regressions (linear and censored) analysis; censored regression, where the structural responses are unexpectedly high, has been used to prevent large bias in the fragility functions. The parameters of 
the best-fit curve ( $a$ and $b$ ) in the linear regression analysis (considering all observations) compute utilizing the Maximum Likelihood Method (MLE) (Lallemant et al. 2015; Stafford 2008), by the Eq. (3). In the following equation, $\phi$ stands for the probability density function of the standard Gaussian distribution.

$$
L=\prod_{i=1}^{n}\left[\phi\left(\frac{E D P_{i}-a-b I M_{i}}{\sigma}\right)\right]
$$

3

A factor equal to 1.5 has been determined for censored regression analysis (Schnedler 2005), representing the ratio between maximum allowable EDP and the last limit state (e.g., Complete). Considering this certain threshold (EDP ${ }_{c}$ $=1.5$ * EDP), the observed data (i.e., EDP $\mathrm{i}_{\mathrm{i}}$ ) is divided into two categories: the uncensored $\left(\mathrm{n}_{\mathrm{o}}\right)$ and the censored $\left(\mathrm{n}_{\mathrm{c}}\right)$ observations. A step-by-step description of this process (with or without the censored regression) can be found in (Martins and Silva, 2020). Fig. 6b depicted these data points using circles and squares, respectively, for a 5-storey steel moment frame structure. For the censored regression analysis (e.g., Stafford 2008), the following equation has been utilized, where $\Phi$ stands for the cumulative function of the standard Gaussian distribution:

$$
\ln (L)=\sum_{j=1}^{n_{c}}\left[\ln \left(1-\Phi\left(\frac{E D P_{C}-a-b I M_{j}}{\sigma}\right)\right)\right]+\sum_{i=1}^{n_{o}}\left[\ln \varphi\left(\frac{E D P_{i}-a-b I M_{i}}{\sigma}\right)\right]
$$

\section{4}

As mentioned earlier, the two types of uncertainty which exist in fragility analysis are as follows:

$\sigma_{\text {rec-to-rec }}$ which corresponds to record-to-record variability has been considered by employing a large set of ground motion records.

$\sigma_{\text {building-to-building }}$ corresponding to building-to-building variability, which according to Martins and Silva (2020), can be considered in two different methods. The first method is to consider a large number of numerical models (backbone curves) per building class (Erberik 2008b, a; Villar-Vega et al. 2017). The second method is to increase the standard deviation directly, which decreases the volume and time of needed computations. In this study, a value of 0.3 has been considered as the building-to-building variability. So considering $\sigma_{\text {rec-to-rec }}$ and $\sigma_{\text {building-to-building, }}$ the total uncertainty $\left(\sigma_{\text {total }}\right)$ is computed according to Eq. (7).

$$
\sigma_{\text {total }}=\sqrt{\left(\sigma_{\text {rec }- \text { to }- \text { rec }}\right)^{2}+\left(\sigma_{\text {building-to-building }}\right)^{2}}
$$

5

So the fragility function developed based on the Cloud analysis can be expressed as Eq. (8):

$$
P\left[L S \geq l s_{i} \mid I M\right]=\varphi\left(\frac{\ln E D P_{1 s_{i}}-E[\ln E D P \mid \ln I M]}{\sigma_{\text {total }}}\right)
$$


In the aforementioned equation, $(P[L S \geq I s i \mid I M])$ is the probability of exceeding a certain limit state for a given intensity measure, and $\mathrm{EDP}_{\mathrm{Isi}}$ is the engineering demand parameter (i.e., maximum displacement) for limit state Is $_{\mathrm{i}}$. As previously mentioned, the EDPs corresponding to each damage criteria were fitted to a lognormal distribution in order to consider another source of uncertainty corresponding to the definition of damage criteria. So, with regard to this source of uncertainty, the fragility functions were defined by the following equation:

$$
P\left[L S \geq I s_{i} \mid I M\right]=\sum_{j=1}^{n} \varphi\left(\frac{\ln E D P_{l s_{i, j}}-E[\ln E D P \mid \operatorname{lnIM}]}{\sigma_{\text {total }}}\right) \cdot P\left[E D P_{l s_{i, j}}\right]
$$

7

In the above equation, $P\left[E D P_{\mid s i, j}\right]$ stands for the probability of occurrence of EDP Isi,j, $_{\text {and }} E P_{\mid s i, j}$ is an increment of the possible range of EDPs for damage state Isi. The steps followed for the fragility assessment using cloud analysis are illustrated in Fig. 7, while the probability of exceedance for three Intensity Measure Levels (IMLs) given a considered Limit State $\left(\mathrm{LS}_{\mathrm{i}}\right)$ is illustrated in the left panel of Fig. 7. The hatched area under the probability density functions illustrated in the left panel presented the probability of exceeding $L S_{i}$ for three IMLs. The resulting probability of $L S_{i}$ for three IMLs is plotted as data points on the right panel. For the purpose of this study, four types of intensity measures have been considered in fragility analysis, which were selected based on the yield period of each building type.

\section{Results}

\subsection{Results of the capacity curves}

In this section, the results have been presented only for MBTs. The assumed MBTs for Iranian buildings taxonomy are shown in Table 3. As discussed earlier, an SDOF system was generated for each building type, considering the associated structural and dynamic properties presented in Table 4. These structural and dynamic properties were used to derive a generic backbone curve for each building type. The resulted generic Two-Linear backbone curves for MBTs have been shown in Table 5.

\subsection{Results of the fragility functions}

This section presents the resulting fragility parameters for the steel and wooden MBTs, were listed in Table 6. The resulting fragility parameters for other model building types are provided in Appendix A. As described in Table 6, the resulted fragility parameters are presented with the logarithmic mean $(\theta)$ and standard deviation $(\beta)$ values. The Intensity Measure Types (IMT) for the derivation of fragility functions were selected considering the fundamental period of each building type. These IMTs were presented in Table 6. Fig. 8 shows the resulted fragility curves for some MBTs.

\section{Comparison Of The Fragility Curves With Empirical Data Derived From Past Earthquakes In Iran}

To clarify the validity of proposed fragility curves a comparison has been provided between the presented fragility functions and damages observed during the past earthquakes in the country. To this aim, observed damage data 
from Iran's past earthquakes, from 1970 to 2017, have been collected. The information related to Iran's major past earthquakes has been described in Table 7 ( Sadeghi et al. 2015; Fallah Tafti et al. 2020).

Due to the lack of detailed and sufficient information on Iran's past earthquake damages for different building types, the comparison has been accomplished only for some building types. The comparison between the fragility functions proposed in this study with the observed damage from past earthquakes has been illustrated for some building types in Fig. 9. The damages data due to past earthquakes in Iran, which have been extracted from past research (Sadeghi et al. 2015; Izanloo and Yahyaabadi 2018; Biglari and Formisano 2020; Biglari et al. 2021), provided fragility curves based on PGA. In this study, these damage data were converted into Sa (0.3 s) and Sa (0.6 s) by using the PGA to Sa ratio extracted from the ground motion records used in this study. As shown in Figs. 9, it can be claimed that the fragility curves proposed in this study have mainly a good and appropriate agreement with observed damage data derived from past earthquakes in Iran.

\section{Summary And Conclusion}

Developing fragility functions is one of the most important steps in seismic risk assessment. The lack of comprehensive and reliable fragility functions for common buildings in Iran is an essential gap to evaluate the extent of damage to buildings due to the potential earthquake hazard. For this reason, an extensive review was performed on previous studies in the country, and their useful data have been collected. The extracted data have been utilized to identify all common buildings in Iran and develop cogent fragility functions for them. This work has been done through the following steps:

1. In the initial step, by conducting comprehensive studies, common buildings in Iran were identified and divided into 35 categories based on the type of materials, lateral resisting system, height, and code level.

2. Then, considering structural and dynamic parameters, an equivalent single-degree-of-freedom oscillator with a generic backbone curve and a hysteresis behavior has been defined for buildings in each class.

3. A large collection of ground motion records has been provided from the IIEES SGMR Toolbox.

4. The non-linear time-history analyses were performed on SDOF systems defined for each building class utilizing a set of 300 ground motion records.

5. Finally, approximately 300 fragility functions were developed for Iranian building taxonomy using cloud analysis methodology proposed by Jalayer et al. (2015)

6. The developed fragility functions have been compared with experimental data from past earthquakes in Iran. The results showed that generated fragility functions follow the empirical data fairly well.

As discussed earlier, the fragility functions developed in this study have been mainly in good agreement with empirical data from past earthquakes. So, the proposed fragility functions can be used directly to assess the damage, human and economic losses due to earthquake scenarios, probabilistic risk analysis, and risk management. Lastly, although the obtained results are encouraging, the awareness of the limitations of the current study is significant. These fragility functions have been developed based on a simplified numerical method and expert judgment. So, it is recommended for future studies to focus on: 
- Refining numerical models by using more detailed characteristics of the buildings, proper identification of the structural parameters of the buildings, and considering structural deficiencies.

- Defining more accurate backbone curves for Iranian common building types Based on these numerical models.

- Comprehensive study on some existing building types in the country, which sufficient information has not been existed (such as precast concrete buildings).

- Providing instructions for collecting building damage data for the future events.

These steps allow for a more precise evaluation of the earthquake's impact on Iranian buildings stock, thus obtaining more reliable risk analyses.

\section{Declarations}

\section{Acknowledgments}

The authors would like to thank Luis Martins for his kind help in the process of operating the VMTK software. Also, the authors wish to forward special thanks to the local experts who participated in the "IIEES Fragility Function Working Group," Prof. Behrokh Hosseini Hashemi, Prof. Abdoreza Sarvghad Moghadam, and Prof. Babak Mansouri, for the technical guidance, kind help, and insightful suggestions. Finally, the first author wishes to forward thanks to Amir Reza Taherian for the valuable discussions and helpful comments.

\section{Data Availability Statement:}

The data presented in this study are available on reasonable request from the corresponding author.

\section{Declaration of conflicting interests}

The authors declare that they have no conflict of interest.

\section{Funding information}

The authors received no financial support for the research, authorship, and/or publication of this article.

\section{References}

1. Ahmad N, Crowley H, Pinho R, Ali Q (2010) Displacement-Based Earthquake Loss Assessment of Masonry Buildings in Mansehra City, Pakistan. J Earthq Eng 14:1-37. https://doi.org/10.1080/13632461003651794

2. Aliabadi MH (2016) Comparison between some of reinforced concrete shear wall's modeling methods for nonlinear static and dynamic analysis. M.S Thesis In Civil Engineering, apadana institute of higher education Shiraz, Iran

3. Alizadeh Basban N (2018) Study on the Response Modification Coefficient dual-bending frame of k-shape Eccentrically Braced Steel Frames using Nonlinear Static Pushover Analysis and Incremental Dynamic Analysis. Master of Science (MSc) Thesis, Ghiaseddin Jamshid Kashani Higher Education Institute, Faculty of Civil and Mechanical Engineering

4. Amiri G, Darvishan E, Rokni HR (2012) Deterioration effect of hysteresis loops in nonlinear static analysis of intermediate and special steel moment frames. Asian J Civ Eng 13:499-510 
5. Ashkoo M (2015) Analytical study the effect of distribution of RC bearing walls on seismic performance of tunnel form buildings. MSc. Thesis, University of Science \& Culture, Department Of Civil Engineering

6. ATC-13 (1985) Earthquake damage evaluation data for California. Applied Technology Council, Federal Emergency Management Agency (FEMA), 492 pp, CA

7. Azarbakht A, Mousavi M, Ghafory-Ashtiany M (2012) Adjustment of the Seismic Collapse Fragility Curves of Structures by Considering the Ground Motion Spectral Shape Effects. J Earthq Eng 16:1095-1112. https://doi.org/10.1080/13632469.2012.703384

8. Baker J, Lin T, Shahi S, Jayaram N (2011) New ground motion selection procedures and selected motions for the PEER transportation research program. Pacific Earthquake Engineering Research Center

9. Baker JW (2011) Conditional Mean Spectrum: Tool for Ground-Motion Selection. J Struct Eng 137:322-331. https://doi.org/10.1061/(ASCE)ST.1943-541X.0000215

10. Bal I, Crowley H, Pinho R (2008) Development of a Displacement-Based Earthquake Loss Assessment Method for Turkish Buildings

11. Bal IE, Bommer JJ, Stafford PJ, et al (2010) The Influence of Geographical Resolution of Urban Exposure Data in an Earthquake Loss Model for Istanbul. Earthq Spectra 26:619-634. https://doi.org/10.1193/1.3459127

12. Behrokh H. Hashemi MGA (2002) Semi-rigid steel frame with “Khorjinee” connections. Tehran, Iran

13. Beiranvand A (2017) Appointment of Structural fragility curve approximation using the system a degree of freedom. Master of Science (MSc) Thesis, Vali-e-Asr University of Rafsanjan Faculty of Engineering

14. Biglari M, Formisano A (2020) Damage Probability Matrices and Empirical Fragility Curves From Damage Data on Masonry Buildings After Sarpol-e-zahab and Bam Earthquakes of Iran. Front Built Environ 6:.

https://doi.org/10.3389/fbuil.2020.00002

15. Biglari M, Formisano A, Hashemi BH (2021) Empirical fragility curves of engineered steel and RC residential buildings after Mw 7.3 2017 Sarpol-e-zahab earthquake. Bull Earthq Eng 19:2671-2689. https://doi.org/10.1007/s10518-021-01090-4

16. Borzi B, Crowley H, Pinho R (2008a) Simplified Pushover-Based Earthquake Loss Assessment (SP-BELA) Method for Masonry Buildings. Int J Archit Herit 2:353-376. https://doi.org/10.1080/15583050701828178

17. Borzi B, Pinho R, Crowley H (2008b) Simplified pushover-based vulnerability analysis for large-scale assessment of RC buildings. Eng Struct 30:804-820. https://doi.org/10.1016/j.engstruct.2007.05.021

18. Brzev S, Scawthorn C, Charleson AW, et al (2013) GEM Building Taxonomy Version 2.0. Vol. GEM Technical Report 2013-02 V1.0.0, Pavia,IT: Global Earthquake Model Foundation

19. Calvi G, Pinho R, Crowley H (2006a) State-of-the-knowledge on the period elongation of RC buildings during strong ground shaking

20. Calvi G, Pinho R, Magenes G, et al (2006b) Development of seismic vulnerability assessment methodologies over the past 30 years. ISET J Earthq Technol 43:75-104

21. Calvi GM (1999) A displacement-based approach for vulnerability evaluation of classes of buildings. J Earthq Eng 3:411-438. https://doi.org/10.1080/13632469909350353

22. Camelo V, Beck J, Hall J (2002) Dynamic Characteristics of Woodframe Buildings

23. Colombi M, Borzi B, Crowley $\mathrm{H}$, et al (2008) Deriving vulnerability curves using Italian earthquake damage data. Bull Earthq Eng 6:485-504. https://doi.org/10.1007/s10518-008-9073-6

24. Crowley H, Pinho R (2004) Period-height relationship for existing European reinforced concrete buildings. J Earthq Eng 8:93-119. https://doi.org/10.1080/13632460409350522

Page $14 / 33$ 
25. Crowley H, Pinho R (2009) Revisiting Eurocode 8 formulae for periods of vibration and their employment in linear seismic analysis. Earthq Eng Struct Dyn 39:n/a-n/a. https://doi.org/10.1002/eqe.949

26. Crowley H, Pinho R (2006) Simplified equations for estimating the period of vibration of existing buildings. In: Proceedings of the 1st European conference on earthquake engineering and seismology

27. D’Ayala D, Meslem A, Vamvatsikos D, et al (2015) GEM Guidelines for Analytical Vulnerability Assessment of Low/Mid-Rise Buildings

28. Dolatshahi KM, Nikoukalam MT, Beyer K (2018) Numerical study on factors that influence the in-plane drift capacity of unreinforced masonry walls. Earthq Eng Struct Dyn 47:1440-1459.

https://doi.org/10.1002/eqe.3024

29. Dolšek M, Fajfar P (2008) The effect of masonry infills on the seismic response of a four-storey reinforced concrete frame - a deterministic assessment. Eng Struct 30:1991-2001.

https://doi.org/10.1016/j.engstruct.2008.01.001

30. Dorri F, Ghasemi SH, Nowak A (2019) Developing a Lateral Load Pattern for Pushover Analysis of EBF System. 1:. https://doi.org/10.22115/rer.2019.184387.1009

31. Doulatabadi A (2017) Compare seismic performance of steel building frame construction with simple frame and moment frame in two versions 3 and 4, 2800. Master of Science (M.Sc.) Thesis, Hakim Sabzevari University Faculty of Engineering

32. Dymiotis C, Kappos AJ, Chryssanthopoulos MK (1999) Seismic Reliability of RC Frames with Uncertain Drift and Member Capacity. J Struct Eng 125:1038-1047. https://doi.org/10.1061/(ASCE)07339445(1999)125:9(1038)

33. Entezari Zarch A (2017) Evaluation of Seismic Performance of Steel Buildings Designed in accordance with the 2800 Regulation Using Capacity Spectrum Method and Comparison with each other. The thesis of M.Sc in Technical Engeneering \& sciences Department of Civil Engeneering

34. Erberik MA (2008a) Generation of fragility curves for Turkish masonry buildings considering in-plane failure modes. Earthq Eng Struct Dyn 37:387-405. https://doi.org/10.1002/eqe.760

35. Erberik MA (2008b) Fragility-based assessment of typical mid-rise and low-rise RC buildings in Turkey. Eng Struct 30:1360-1374. https://doi.org/10.1016/j.engstruct.2007.07.016

36. Esmaeili H, Kheyroddin A, Naderpour H (2013) Seismic Behavior of Steel Moment Resisting Frames Associated with RC Shear Walls. Iran J Sci Technol Trans B Eng 37:395-407

37. Etezadi Ghozhdi SA (2012) Comparison of the Special Concentric Braces with Pushover Analysis. The Dissertation of M.Sc. in Structure Engineering, The University of Sistan \& Baluchestan

38. Fallah Tafti M, Amini Hosseini K, Mansouri B (2020) Generation of new fragility curves for common types of buildings in Iran. Bull Earthq Eng 18:3079-3099. https://doi.org/10.1007/s10518-020-00811-5

39. Gerami M, Sharbati Y, Sivandi-pour A (2013) Nonlinear seismic vulnerability evaluation of irregular steel buildings with cumulative damage indices. https://doi.org/10.1186/2008-6695-5-9

40. Ghafory-Ashtiany M, Mousavi M, Azarbakht A (2014) Epsilon as an indicator of ground motion spectral shape. Sharif J Civ Eng Volume 29-:109-115

41. Ghafory-Ashtiany M, Mousavi M, Azarbakht A (2011) Strong ground motion record selection for the reliable prediction of the mean seismic collapse capacity of a structure group. Earthq Eng $\backslash \&$ Struct Dyn 40:691-708

42. Ghafory-Ashtiany M, Shokoohi S, Ansari A (2021) The recently compiled strong-motion database catalog for Iran. Manuscript in preparation. 
43. Gholizad A, Safari H (2014) Seismic fragility curves for mid-rise RC frames designed according to Iranian seismic code. Asian J Civ Eng 15:803-815

44. Goda K (2015) Record selection for aftershock incremental dynamic analysis. Earthq Eng Struct Dyn 44:11571162. https://doi.org/10.1002/eqe.2513

45. Haj Najafi L, Tehranizadeh M (2013) Evaluation of seismic behavior for moment frames and eccentrically braced frames due to near-field ground motions. Asian J Civ Eng 14:809-830

46. Hamzeh L, Ashour A, Galal K (2018) Development of Fragility Curves for Reinforced-Masonry Structural Walls with Boundary Elements. J Perform Constr Facil 32:04018034. https://doi.org/10.1061/(ASCE)CF.19435509.0001174

47. Hassani B, Jafari A (2012) An investigation on the seismic performance of reinforced concrete panel structures. ASIAN J Civ Eng (BUILDING HOUSING) 13:181-193

48. HAZUS (1999) Earthquake loss estimation methodology-technical and user manuals. Federal Emergency Management Agency, Washington DC

49. Heidari PS, Kayhani H, Jazany RA (2010) Effects of x-bracing resistant system configuration on limit state behavior in steel frames using pushover analysis

50. Hosseini Hashemi B, Hassanzadeh M (2008) Study of a semi-rigid steel braced building damaged in the Bam earthquake. J Constr Steel Res 64:704-721. https://doi.org/https://doi.org/10.1016/j.jcsr.2007.12.007

51. Hosseini SA, Ruiz-Garcia J, Massumi A (2019) Seismic response of RC frames under far-field mainshock and near-fault aftershock sequences. Struct Eng Mech 72:395-408. https://doi.org/10.12989/sem.2019.72.3.395

52. Ibarra L, Krawinkler H (2005) Global Collapse of Frame Structures Under Seismic Excitations

53. ICSRDB (2014) Iranian code of practice for seismic resistant design of buildings, Standard 2800, 4th edn. Building and Housing Research Center, Tehran, Tehran, Iran

54. ICSRDB (1999) Iranian code of practice for seismic resistant design of buildings, Standard 2800, Second edn. Building and Housing Research Center, Tehran, Iran

55. INBC Part 8 (2013) Iranian National Building Code (INBC), Part 8: Masonry Structures. Ministry of Housing and Urban Development, Tehran, Iran.

56. INBC Part 9 (2013) Iranian National Building Code (INBC), Part 9: Concrete Structures. Ministry of Housing and Urban Development, Tehran, Iran.

57. INBC Part10 (2013) Iranian National Building Code (INBC), Part 10: Steel Structures. Ministry of Housing and Urban Development, Tehran, Iran.

58. Izanloo F, Yahyaabadi A (2018) Determination of Structural Fragility Curves of Various Building Types For Seismic Vulnerability Assessment in the Sarpol-e Zahab City. J Seismol Earthq Eng 20:93-107

59. Jahangir H, Karamodin A (2015) Structural Behavior Investigation Based on Adaptive Pushover Procedure

60. Jaiswal K, Aspinall WP, Perkins DM, et al (2012) Use of expert judgment elicitation to estimate seismic vulnerability of selected building types. Proceedings of 15th world conference on earthquake engineering, Lisbon, Portugal, pp 24-28

61. Jaiswal K, Wald D, Porter K (2010) A Global Building Inventory for Earthquake Loss Estimation and Risk Management. Earthq Spectra 26:731-748. https://doi.org/10.1193/1.3450316

62. Jalayer F, De Risi R, Manfredi G (2015) Bayesian Cloud Analysis: efficient structural fragility assessment using linear regression. Bull Earthq Eng 13:1183-1203. https://doi.org/10.1007/s10518-014-9692-z 
63. Jayaram N, Lin T, Baker J (2011) A Computationally Efficient Ground-Motion Selection Algorithm for Matching a Target Response Spectrum Mean and Variance. Earthq Spectra 27:797-815.

https://doi.org/10.1193/1.3608002

64. Kalantari A, Roohbakhsh H, Taherian AR (2020) Seismic fragility assessment of RC moment resisting frame buildings designed for different editions of Iranian seismic design code. Disaster Prev Manag Knowl 10:

65. Kazemi H, Ghafory-Ashtiany M, Azarbakht A (2017) Development of fragility curves by incorporating new spectral shape indicators and a weighted damage index: case study of steel braced frames in the city of Mashhad, Iran. Earthq Eng Eng Vib 16:383-395. https://doi.org/10.1007/s11803-017-0388-7

66. Kazemi H, Ghafory-Ashtiany M, Azarbakht A (2013) Effect of epsilon-based record selection on fragility curves of typical irregular steel frames with concrete shear walls in Mashhad city. Int J Adv Struct Eng 5:23. https://doi.org/10.1186/2008-6695-5-23

67. Khoshnoud H (2010) Evaluating equivalent static analysis of Iranian code with nonlinear static pushover analysis

68. Khoshnoud HR, Marsono AK (2011) Evaluation of seismic behaviour of masonry infills in RC frame by pushover analysis. In: 6th International Conference on Seismology and Earthquake Engineering. undefined, Tehran, Iran

69. Khoshnoudian F, Mestri S, Abedi-Nik F (2011) Proposal of lateral load pattern for pushover analysis of RC buildings

70. Kiani A, Mansouri B, Moghadam AS (2016) Fragility curves for typical steel frames with semi-rigid saddle connections. J Constr Steel Res 118:231-242. https://doi.org/10.1016/j.jcsr.2015.11.001

71. Kohrangi M, Bazzurro P, Vamvatsikos D (2021) Seismic risk and loss estimation for the building stock in Isfahan. Part I: exposure and vulnerability. Bull Earthq Eng 19:1709-1737. https://doi.org/10.1007/s10518020-01036-2

72. Lagomarsino S, Giovinazzi S (2006) Macroseismic and mechanical models for the vulnerability and damage assessment of current buildings. Bull Earthq Eng 4:415-443. https://doi.org/10.1007/s10518-006-9024-z

73. Lallemant D, Kiremidjian A, Burton H (2015) Statistical procedures for developing earthquake damage fragility curves. https://doi.org/10.1002/eqe.2522

74. Lookzadeh AH (2020) Investigation of the performance of damaged steel buildings after Sarpol-e- Zahab earthquake. Master of Science Thesis, International Institute of Earthquake Engineering and Seismology (IIEES)

75. Lotfy I, Mohammadalizadeh T, Ahmadi F, Soroushian S (2019) Fragility Functions for Displacement-based Seismic Design of Reinforced Masonry Wall Structures. J Earthq Eng 00:1-19.

https://doi.org/10.1080/13632469.2019.1659881

76. Maddah MM, Eshghi S (2018) Evaluation of a Seismic Collapse Assessment Methodology Based on the Collapsed Steel Buildings Data in Sarpol-e Zahab, Iran Earthquake. 20:

77. Mahdi T (2009) Pushover analysis of asymmetric ordinary moment RC frames designed according to the Iranian codes

78. Mahdi T, Soltangharaei V (2011) Plan irregular RC frames: Comparison of pushover with nonlinear dynamic analysis. Asian J Civ Eng 12:679-690

79. Mahmoudi M, Zaree M (2011) Evaluating the overstrength of concentrically braced steel frame systems considering members post-buckling strength. Int J Civ Eng 9:57-62 
80. Mahmoudi M, Zaree M (2012) Performance based design using force reduction factor and displacement amplification factors for BFS. Asian J Civ Eng 14:577-586

81. Mahmoudi M, Zaree M (2013) Evaluating the displacement amplification factors of concentrically braced steel frames. Int J Adv Struct Eng 5:. https://doi.org/10.1186/2008-6695-5-13

82. Mansouri B, Amini-Hosseini K (2013) “Global Earthquake Risk Model (GEM) - Earthquake Model of the Middle East Region (EMME),Final Report of Work Package 4, WP4: Seismic Risk Assessment”, Final Report, 2013, IIEES internal contract \#AM 7-269 (15/5/90). Tehran, Iran

83. Martins L, Silva V (2020) Development of a fragility and vulnerability model for global seismic risk analyses. Bull Earthq Eng. https://doi.org/10.1007/s10518-020-00885-1

84. Martins L, Silva V, Crowley H, Cavalieri F (2021) Vulnerability modellers toolkit, an open-source platform for vulnerability analysis. Bull Earthq Eng 19:5691-5709. https://doi.org/10.1007/s10518-021-01187-w

85. McKenna F, Fenves G, Scott M JB (2000) Open system for Earthquake Engineering Simulation (OpenSees). Pacific Earthquake Engineering Research Center. University of California, Berkeley, CA

86. Mehdizadeh K, Karamodin A (2017) Probabilistic assessment of steel moment frames incremental collapse (ordinary, intermediate and special) under earthquake. J Struct Constr Eng 4:129-147.

https://doi.org/10.22065/jsce.2017.75370.1066

87. Mobarrez Chini Belagh R (2016) Computing of fragility spectrum for mid rise steel frame structures regarding to evaluation of story cumulative damage indices strategies. Master of Science Thesis, Semnan University Faculty of Civil Engineering

88. Moghaddasi SS (2014) No TitleAssess Different Methods of Non-linear Static Analysis on the Frame with the Dual system. Master of Science Thesis, Ferdowsi University of Mashhad, Department of Civil Engineering

89. Mohandesi MA, Azarbakht A, Ghafory-Ashtiany M (2019) The conditional mean spectra by disaggregating the eta spectral shape indicator. Struct Des Tall Spec Build 28:e1586. https://doi.org/10.1002/tal.1586

90. Mohsenian V, Filizadeh R, Ozdemir Z, Hajirasouliha I (2020a) Seismic performance evaluation of deficient steel moment-resisting frames retrofitted by vertical link elements. Structures 26:724-736.

https://doi.org/10.1016/j.istruc.2020.04.043

91. Mohsenian V, Hajirasouliha I, Mariani S, Nikkhoo A (2020b) Seismic reliability assessment of RC tunnel-form structures with geometric irregularities using a combined system approach. Soil Dyn Earthq Eng 139:106356. https://doi.org/10.1016/j.soildyn.2020.106356

92. Mohsenian V, Nikkhoo A, Rostamkalaee S, et al (2021) The seismic performance of tunnel-form buildings with a non-uniform in-plan mass distribution. Structures 29:993-1004. https://doi.org/10.1016/j.istruc.2020.11.063

93. Mortezaei A, Ronagh HR (2013) Effectiveness of modified pushover analysis procedure for the estimation of seismic demands of buildings subjected to near-fault ground motions having fling step. Nat Hazards Earth Syst Sci 13:1579-1593. https://doi.org/10.5194/nhess-13-1579-2013

94. Motamed H, Calderon A, Silva V, Costa C (2019) Development of a probabilistic earthquake loss model for Iran. Bull Earthq Eng 17:1795-1823. https://doi.org/10.1007/s10518-018-0515-5

95. Mouroux P, Le Brun B (2006) Risk-Ue Project: An Advanced Approach to Earthquake Risk Scenarios With Application to Different European Towns. In: Oliveira CS, Roca A, Goula X (eds) Assessing and Managing Earthquake Risk. Springer Netherlands, Dordrecht, pp 479-508

96. Mousavi M, Ghafory-Ashtiany M, Azarbakht A (2011) A new indicator of elastic spectral shape for the reliable selection of ground motion records. Earthq Eng Struct Dyn 40:1403-1416. https://doi.org/10.1002/eqe.1096

Page $18 / 33$ 
97. Namjouyan MA (2013) Evaluation of Seismic Performance of Irregular RC Frames in Height. Master of Science Thesis, Shahid Bahonar University of Kerman, Department of Civil Engineering

98. Nasserasadi K, Ghafory-As M, Eshghi S, Zolfaghari MR (2008) Developing Seismic Fragility Function of Structures by Stochastic Approach. J Appl Sci 8:975-983. https://doi.org/10.3923/jas.2008.975.983

99. Nassirpour A, D’Ayala D (2014) Fragility analysis of mid-rise masonry in-filled steel frame (MISF) structures

100. Omidvar B, Gatmiri B, Derakhshan S (2012) Experimental vulnerability curves for the residential buildings of Iran. Nat Hazards 60:345-365. https://doi.org/10.1007/s11069-011-0019-y

101. Pitilakis K, Crowley H, Kaynia AM (2014) SYNER-G: Typology Definition and Fragility Functions for Physical Elements at Seismic Risk: Buildings, Lifelines, Transportation Networks and Critical Facilities. SYNER-G Typology Defin Fragility Funct Phys Elem Seism Risk

102. Pourmoghadam H (2017) Study on the Response Modification Coefficient of Eccentrically Braced Special Steel Frames with Vertical Shear Link using Nonlinear Static Pushover Analysis and Incremental Dynamic Analysis. M.Sc. Thesis, Ghiaseddin Jamshid Kashani Higher Education Institute Faculty of Civil Engineering

103. Poursha M, Khoshnoudian F, S. Moghadam A (2011) A consecutive modal pushover procedure for nonlinear static analysis of one-way asymmetric plan tall building structures. Eng Struct 33:2417-2434. https://doi.org/10.1016/j.engstruct.2011.04.013

104. Preciado A, Ramirez-Gaytan A, Santos JC, Rodriguez O (2020) Seismic vulnerability assessment and reduction at a territorial scale on masonry and adobe housing by rapid vulnerability indicators: The case of Tlajomulco, Mexico. Int J Disaster Risk Reduct 44:101425. https://doi.org/10.1016/j.ijdrr.2019.101425

105. Rahmani Qeranqayah M (2014) Probabilistic Seismic Performance Assessment of Multistorey Steel Moment Resisting Frame Accompanied with Reinforced Concrete Shear Wall. Master of Science (M.Sc.) In Earthquake Engineering, K. N. Toosi University of Technology Faculty of Civil Engineering

106. Rahmani Y, Bourahla N, Bento R, Badaoui M (2018) An improved upper-bound pushover procedure for seismic assessment of high-rise moment resisting steel frames. Bull Earthq Eng 16:. https://doi.org/10.1007/s10518017-0204-9

107. Raji R (2012) Applicability of pushover analysis to structures with shear wall. Master of Science (M.Sc.) Thesis, University of Tabriz Department of Civil Engineering

108. Ranjbaran F, Hosseini M, Soltani M (2012) Simplified formulation for modeling the nonlinear behavior of confined masonry walls in seismic analysis. Int $\mathrm{J}$ Archit Herit 6:259-289.

https://doi.org/10.1080/15583058.2010.528826

109. Riahi Z, Elwood KJ, Alcocer SM (2009) Backbone Model for Confined Masonry Walls for Performance-Based Seismic Design. J Struct Eng 135:644-654. https://doi.org/10.1061/(ASCE)ST.1943-541X.0000012

110. Rigi A (2018) Comparison of seismic behavior of semi-rigid and rigid steel moment resisting frames through incremental dynamic analysis. M.Sc. Thesis, Shiraz University of Technology Department of Civil and Environmental Engineering

111. Rossetto T, Elnashai A (2005) A new analytical procedure for the derivation of displacement-based vulnerability curves for populations of RC structures. Eng Struct 27:397-409.

https://doi.org/10.1016/j.engstruct.2004.11.002

112. Rossetto T, loannou I, Grant D, Maqsood T (2014) Guidelines for empirical vulnerability assessment. GEM Technical Report 2014-08 V1.0.0, Global Earthquake Model Foundation, Pavia, Italy 
113. Sabetta F, Goretti A, Antonio L (1998) Empirical fragility curves from damage surveys and estimated strong ground motion. 11th European conference on earthquake engineering, $p$

114. Sadeghi M, Ghafory-Ashtiany M, Pakdel-Lahiji N (2015) Developing seismic vulnerability curves for typical Iranian buildings. Proc Inst Mech Eng Part O J Risk Reliab 229:627-640. https://doi.org/10.1177/1748006X15596085

115. Samadian D, Ghafory-Ashtiany M, Naderpour H, Eghbali M (2019) Seismic resilience evaluation based on vulnerability curves for existing and retrofitted typical RC school buildings. Soil Dyn Earthq Eng 127:105844. https://doi.org/10.1016/j.soildyn.2019.105844

116. Sarokolayi LK, Dehkordib SG, Sefidabc MS (2015) Evaluating Response Modification Factors of Concentrically Braced and Special Moment Steel Frames in Duplex Buildings. J Struct Eng Geo-Techniques 5:31-38

117. Sartaji P, Sarvghad Moghadam A, Ashtiany MG (2017) Practical modelling issues for masonry building retrofitted with squat shear wall. Struct Des Tall Spec Build 26:e1380. https://doi.org/10.1002/tal.1380

118. Schnedler W (2005) Likelihood Estimation for Censored Random Vectors. https://doi.org/10.1081/ETC200067925

119. Shabani A, Kioumarsi M, Zucconi M (2021) State of the art of simplified analytical methods for seismic vulnerability assessment of unreinforced masonry buildings. Eng Struct 239:112280. https://doi.org/10.1016/j.engstruct.2021.112280

120. Shokrollahi Yancheshmeh A (2014) Calculating the behavior factor of ordinary buildings with tunnel form system. MSc. Thesis, University of Science and Culture Department of Civil Engineering

121. Silva V, Akkar S, Baker J, et al (2019) Current challenges and future trends in analytical fragility and vulnerability modeling. Earthq Spectra 35:1927-1952. https://doi.org/10.1193/042418EQS1010

122. Silva V, Casotto C, Vamvatsikos D, et al (2017) Presentation of the Risk Modeller's Toolkit, the open-source software for vulnerability assessment of the Global Earthquake Model. 16th World Conf Earthq Eng

123. Silva V, Crowley H, Varum H, et al (2014a) Evaluation of analytical methodologies used to derive vulnerability functions. Earthq Eng Struct Dyn 43:. https://doi.org/10.1002/eqe.2337

124. Silva V, Crowley H, Varum H, et al (2014b) Investigation of the characteristics of Portuguese regular momentframe RC buildings and development of a vulnerability model. Bull Earthq Eng 13:1455-1490. https://doi.org/10.1007/s10518-014-9669-y

125. Stafford PJ (2008) Short Note Conditional Prediction of Absolute Durations. 98:1588-1594. https://doi.org/10.1785/0120070207

126. Statistical Center of Iran (SCI) (2018) Building inventory statistical data 2018-2019. https://www.amar.org.ir/english/Population-and-Housing-Censuses

127. Tarque N, Crowley H, Pinho R, Varum H (2012) Displacement-Based Fragility Curves for Seismic Assessment of Adobe Buildings in Cusco, Peru. Earthq Spectra 28:759-794. https://doi.org/10.1193/1.4000001

128. Tavakoli B, Favakoli A (1993) Estimating the vulnerability and loss functions of residential buildings. Nat Hazards 7:155-171. https://doi.org/10.1007/BF00680428

129. Tavakoli G-A and (1999) Seismic hazard assessment of Iran

130. Tavakoli HR, Rashidi Alashti A (2013) Evaluation of progressive collapse potential of multi-story moment resisting steel frame buildings under lateral loading. Sci Iran 20:77-86.

https://doi.org/10.1016/j.scient.2012.12.008

Page 20/33 
131. Tavakoli S (2016) Evaluation of seismic behavior of reinforced concrete moment frame system with shear wall. M.Sc Thesis, Islamic Azad University Taft Branch Faculty of Engineering

132. Tehranizadeh M, Yakhchalian M (2011) Displacement based and consolidated force/displacement based methods for seismic assessment of steel moment resisting frames. Sci Iran 18:1054-1060.

https://doi.org/10.1016/j.scient.2011.08.002

133. Vamvatsikos D (2011) Software - earthquake, steel dynamics and probability, viewed January 2021. http:// users. ntua. gr/ divam va/ softw are. html

134. Villar-Vega M, Silva V, Crowley H, et al (2017) Development of a Fragility Model for the Residential Building Stock in South America. Earthq Spectra 33:581-604. https://doi.org/10.1193/010716EQS005M

135. Zare M, Kamranzad F, Parcharidis I, Tsironi V (2017) Preliminary report of Mw7.3 Sarpol-e Zahab, Iran earthquake on November 12, 2017

\section{Tables}

Due to technical limitations, table $1 \& 4$ is only available as a download in the Supplemental Files section.

Table 2 Iranian buildings classification based on the year of construction

\begin{tabular}{|c|c|c|c|c|c|}
\hline \multirow[t]{3}{*}{$\begin{array}{l}\text { No. of } \\
\text { edition }\end{array}$} & \multicolumn{4}{|c|}{$\begin{array}{l}\text { History of STD-2800, and National } \\
\text { Building Codes }\end{array}$} & \multirow[t]{3}{*}{$\begin{array}{l}\text { Iranian buildings classification based on the year of } \\
\text { construction in this study }\end{array}$} \\
\hline & \multicolumn{3}{|c|}{$\begin{array}{l}\text { National Building } \\
\text { Codes }\end{array}$} & \multirow[t]{2}{*}{$\begin{array}{l}\text { STD- } \\
2800\end{array}$} & \\
\hline & $\begin{array}{l}\text { Part } \\
10\end{array}$ & $\begin{array}{l}\text { Part } \\
9\end{array}$ & $\begin{array}{l}\text { Part } \\
8\end{array}$ & & \\
\hline $\begin{array}{l}1^{\text {st }} \\
\text { Edition }\end{array}$ & 1986 & 1986 & 2005 & 1987 & Prior to 1990 \\
\hline $\begin{array}{l}2^{\text {nd }} \\
\text { Edition }\end{array}$ & 2005 & 2006 & 2013 & 1999 & 1990-2006 \\
\hline $\begin{array}{l}3^{\text {rd }} \\
\text { Edition }\end{array}$ & 2008 & 2009 & - & 2007 & 2006-2016 \\
\hline $\begin{array}{l}4^{\text {th }} \\
\text { Edition }\end{array}$ & 2013 & 2013 & - & 2014 & After 20 \\
\hline
\end{tabular}

Table 3 Iranian buildings taxonomy, Taxonomy IDs and their descriptions and Selected Model Building Types in this study 


\begin{tabular}{|c|c|c|c|c|c|}
\hline \multirow{2}{*}{ No. } & \multirow{2}{*}{ Label } & \multirow{2}{*}{ ID } & \multirow{2}{*}{ Description } & \multicolumn{2}{|c|}{ Height } \\
\hline & & & & Range & MBT \\
\hline 1 & S1L & S1L_MRF_H (1:10) & \multirow{3}{*}{ Steel moment frames } & $1-3$ & 2 \\
\hline 2 & S1M & S1M_MRF_H (1:10) & & $4-7$ & 5 \\
\hline 3 & $\mathrm{~S} 1 \mathrm{H}$ & S1H_MRF_H $(1: 10)$ & & +8 & 8 \\
\hline 4 & S2L & S2L_INFF_H $(1: 10)$ & \multirow{3}{*}{ Steel infilled frames } & $1-3$ & 2 \\
\hline 5 & S2M & S2M_INFF_H $(1: 10)$ & & $4-7$ & 5 \\
\hline 6 & $\mathrm{~S} 2 \mathrm{H}$ & S2H_INFF_H $(1: 10)$ & & +8 & 8 \\
\hline 7 & S3L & S3L_MRF\&CSW_H $(4: 10)$ & \multirow{3}{*}{$\begin{array}{l}\text { Steel frames with concrete } \\
\text { shear walls }\end{array}$} & \multirow{3}{*}{$\begin{array}{l}4-7 \\
+8\end{array}$} & \multirow{3}{*}{$\begin{array}{l}5 \\
8\end{array}$} \\
\hline 8 & S3M & S3M_MRF\&CSW_H $(4: 10)$ & & & \\
\hline 9 & $\mathrm{~S} 3 \mathrm{H}$ & S3H_MRF\&CSW_H $(4: 10)$ & & & \\
\hline 10 & S4L & S4L_SBR_H (1:10) & \multirow{3}{*}{ Steel braced frame } & $1-3$ & 2 \\
\hline 11 & S4M & S4M_SBR_H $(1: 10)$ & & $4-7$ & 5 \\
\hline 12 & $\mathrm{~S} 4 \mathrm{H}$ & S4H_SBR_H $(1: 10)$ & & +8 & 8 \\
\hline 13 & S5L & S5L_DUAL_H (1:10) & \multirow{3}{*}{ Steel frames with dual system } & $1-3$ & 2 \\
\hline 14 & S5M & S5M_DUAL_H (1:10) & & $4-7$ & 5 \\
\hline 15 & $\mathrm{~S} 5 \mathrm{H}$ & S5H_DUAL_H $(1: 10)$ & & +8 & 8 \\
\hline 16 & $\mathrm{~S} 6 \mathrm{~L}$ & S6L_SBR_H (1:7) & Steel braced frames with & $1-3$ & 2 \\
\hline 17 & S6M & S6M_SBR_H (1:7) & Khorjini connections & $4-7$ & 5 \\
\hline 18 & $\mathrm{C} 1 \mathrm{~L}$ & C1L_MRF_H (1:10) & \multirow{3}{*}{$\mathrm{RC}$ moment frames } & $1-3$ & 2 \\
\hline 19 & $\mathrm{C} 1 \mathrm{M}$ & C1M_MRF_H $(1: 10)$ & & $4-7$ & 5 \\
\hline 20 & $\mathrm{C} 1 \mathrm{H}$ & C1H_MRF_H $(1: 10)$ & & +8 & 8 \\
\hline 21 & $\mathrm{C} 2 \mathrm{~L}$ & C2L_INFF_H $(1: 10)$ & \multirow{3}{*}{$\begin{array}{l}\text { Reinforced concrete infilled } \\
\text { frame }\end{array}$} & $1-3$ & \multirow{3}{*}{$\begin{array}{l}5 \\
8\end{array}$} \\
\hline 22 & $\mathrm{C} 2 \mathrm{M}$ & C2M_INFF_H $(1: 10)$ & & $4-7$ & \\
\hline 23 & $\mathrm{C} 2 \mathrm{H}$ & C2H_INFF_H $(1: 10)$ & & +8 & \\
\hline 24 & C3L & C3L_CSW_H $(4: 10)$ & \multirow{3}{*}{$\mathrm{RC}$ frames with shear wall } & \multirow{3}{*}{$\begin{array}{l}4-7 \\
+8\end{array}$} & 2 \\
\hline 25 & $\mathrm{C} 3 \mathrm{M}$ & C3M_CSW_H $(4: 10)$ & & & 5 \\
\hline 26 & $\mathrm{C} 3 \mathrm{H}$ & $\mathrm{C} 3 \mathrm{H}_{-} \mathrm{CSW}_{-}{ }_{-}^{-} \mathrm{H}(4: 10)$ & & & 8 \\
\hline 27 & $\mathrm{C} 4 \mathrm{~L}$ & C4L_TUF_H $(1: 10)$ & \multirow{3}{*}{ RC tunnel-form } & $1-3$ & 2 \\
\hline 28 & C4M & C4M_TUF_H $(1: 10)$ & & $4-7$ & 5 \\
\hline 29 & $\mathrm{C} 4 \mathrm{H}$ & C4H_TUF_H $(1: 10)$ & & +8 & 8 \\
\hline 30 & CML & $\mathrm{CML}_{-} \mathrm{H}(1: 3)$ & \multirow{3}{*}{ Confined masonry buildings } & \multirow{3}{*}{$1-3$} & 2 \\
\hline 31 & $\mathrm{CMM}$ & $\mathrm{CMM}_{-} \mathrm{H}(1: 3)$ & & & 5 \\
\hline 32 & $\mathrm{CMH}$ & $\mathrm{CMH}_{-} \mathrm{H}(1: 3)$ & & & 8 \\
\hline 33 & UM & UM_H (1:3) & Unreinforced masonry buildings & $1-3$ & 2 \\
\hline 34 & WD & WD- H (1:3) & Wooden structure buildings & $1-3$ & 2 \\
\hline 35 & Adobe & ADOBE_H (1:3) & Adobe structure buildings & $1-3$ & 2 \\
\hline
\end{tabular}

Table 5 Generic Two-Linear Capacity curves 


\begin{tabular}{|c|c|c|c|c|c|}
\hline Taxonomy & IMT & $S_{\text {dy }}$ & $S_{d u}$ & $\mathrm{~S}_{\mathrm{ay}}$ & $\mathrm{S}_{\mathrm{au}}$ \\
\hline S1L_MRF_H2 & $\mathrm{Sa}(0.6 \mathrm{~s})$ & 0.0261 & 0.128 & 0.6377 & 0.6377 \\
\hline S1L_MRF_H5 & $\mathrm{Sa}(0.6 \mathrm{~s})$ & 0.0652 & 0.32 & 0.368 & 0.368 \\
\hline S1L_MRF_H8 & $\mathrm{Sa}(1.0 \mathrm{~s})$ & 0.1043 & 0.512 & 0.2776 & 0.2776 \\
\hline S1M_MRF_H2 & $\mathrm{Sa}(0.6 \mathrm{~s})$ & 0.0308 & 0.1754 & 0.7536 & 0.7536 \\
\hline S1M_MRF_H5 & $\mathrm{Sa}(0.6 \mathrm{~s})$ & 0.077 & 0.4385 & 0.4349 & 0.4349 \\
\hline S1M_MRF_H8 & $\mathrm{Sa}(1.0 \mathrm{~s})$ & 0.1233 & 0.7016 & 0.328 & 0.328 \\
\hline S1H_MRF_H2 & $\mathrm{Sa}(0.6 \mathrm{~s})$ & 0.0356 & 0.2228 & 0.8696 & 0.8696 \\
\hline S1H_MRF_H5 & $\mathrm{Sa}(0.6 \mathrm{~s})$ & 0.0889 & 0.557 & 0.5018 & 0.5018 \\
\hline S1H_MRF_H8 & $\mathrm{Sa}(1.0 \mathrm{~s})$ & 0.1422 & 0.8913 & 0.3785 & 0.3785 \\
\hline S3L_MRF\&CSW_H5 & $\mathrm{Sa}(0.6 \mathrm{~s})$ & 0.0296 & 0.1304 & 0.6507 & 0.6507 \\
\hline S3L_MRF\&CSW_H8 & $\mathrm{Sa}(0.6 \mathrm{~s})$ & 0.0474 & 0.2086 & 0.5144 & 0.5144 \\
\hline S3M_MRF\&CSW_H5 & $\mathrm{Sa}(0.6 \mathrm{~s})$ & 0.0474 & 0.1541 & 1.0411 & 1.0411 \\
\hline S3M_MRF\&CSW_H8 & $\mathrm{Sa}(0.6 \mathrm{~s})$ & 0.0759 & 0.2465 & 0.823 & 0.823 \\
\hline S3H_MRF\&CSW_H5 & $\mathrm{Sa}(0.6 \mathrm{~s})$ & 0.0652 & 0.1778 & 1.4315 & 1.4315 \\
\hline S3H_MRF\&CSW_H8 & Sa (0.6s) & 0.1043 & 0.2844 & 1.1317 & 1.1317 \\
\hline S4L_SBR_H2 & $\mathrm{Sa}(0.3 \mathrm{~s})$ & 0.0356 & 0.0948 & 1.389 & 1.389 \\
\hline S4L_SBR_H5 & $\mathrm{Sa}(0.6 \mathrm{~s})$ & 0.0889 & 0.237 & 0.8016 & 0.8016 \\
\hline S4L_SBR_H8 & Sa (1.0s) & 0.1422 & 0.3793 & 0.6046 & 0.6046 \\
\hline S4M_SBR_H2 & $\mathrm{Sa}(0.3 \mathrm{~s})$ & 0.0375 & 0.1233 & 1.4631 & 1.4631 \\
\hline S4M_SBR_H5 & $\mathrm{Sa}(0.6 \mathrm{~s})$ & 0.0936 & 0.3081 & 0.8443 & 0.8443 \\
\hline S4M_SBR_H8 & $\mathrm{Sa}(1.0 \mathrm{~s})$ & 0.1498 & 0.493 & 0.6369 & 0.6369 \\
\hline S4H_SBR_H2 & $\mathrm{Sa}(0.3 \mathrm{~s})$ & 0.0393 & 0.1517 & 1.5372 & 1.5372 \\
\hline S4H_SBR_H5 & $\mathrm{Sa}(0.6 \mathrm{~s})$ & 0.0984 & 0.3793 & 0.8871 & 0.8871 \\
\hline S4H_SBR_H8 & $\mathrm{Sa}(1.0 \mathrm{~s})$ & 0.1574 & 0.6068 & 0.6691 & 0.6691 \\
\hline S5L_DUAL_H2 & $\mathrm{Sa}(0.3 \mathrm{~s})$ & 0.0417 & 0.0853 & 1.7243 & 1.7243 \\
\hline S5L_DUAL_H5 & $\mathrm{Sa}(0.6 \mathrm{~s})$ & 0.1043 & 0.2133 & 0.995 & 0.995 \\
\hline S5L_DUAL_H8 & $\mathrm{Sa}(1.0 \mathrm{~s})$ & 0.1669 & 0.3413 & 0.7505 & 0.7505 \\
\hline S5M_DUAL_H2 & $\mathrm{Sa}(0.3 \mathrm{~s})$ & 0.0441 & 0.1043 & 1.8222 & 1.8222 \\
\hline S5M_DUAL_H5 & $\mathrm{Sa}(0.6 \mathrm{~s})$ & 0.1102 & 0.2607 & 1.0516 & 1.0516 \\
\hline S5M_DUAL_H8 & $\mathrm{Sa}(1.0 \mathrm{~s})$ & 0.1764 & 0.4172 & 0.7932 & 0.7932 \\
\hline S5H_DUAL_H2 & $\mathrm{Sa}(0.3 \mathrm{~s})$ & 0.0465 & 0.1233 & 1.9202 & 1.9202 \\
\hline
\end{tabular}




\begin{tabular}{|llllll|} 
S5H_DUAL_H5 & Sa (0.6s) & 0.1161 & 0.3081 & 1.1081 & 1.1081 \\
\hline S5H_DUAL_H8 & Sa (1.0s) & 0.1858 & 0.493 & 0.8358 & 0.8358 \\
\hline S6L_SBR_H2 & Sa (0.3s) & 0.0091 & 0.032 & 0.6193 & 0.6193 \\
\hline S6L_SBR_H5 & Sa (0.6s) & 0.0229 & 0.08 & 0.3917 & 0.3917 \\
\hline S6M_SBR_H2 & Sa (0.3s) & 0.0114 & 0.0389 & 0.7741 & 0.7741 \\
\hline S6M_SBR_H5 & Sa (0.6s) & 0.0286 & 0.0971 & 0.4896 & 0.4896 \\
\hline WD-H2 & Sa (0.3s) & 0.0057 & 0.0425 & 0.2796 & 0.2796 \\
\hline
\end{tabular}

Table 6 Fragility parameters for steel and wooden Model Building Types (MBT)

Table 7

List of Iran's past earthquakes used for validation of the generated fragility functions

\begin{tabular}{|lll|}
\hline Earthquake & Province & Date \\
\hline Gharnaveh & Golestan & 30 July 1970 \\
\hline Qir-Karzin & Fars & 10 April 1972 \\
\hline Manjil-Rudbar & Gilan & 21 June 1990 \\
\hline Manjil-Rudbar (Manjil) & Gilan & 21 June 1990 \\
\hline Manjil-Rudbar (Rudbar) & Gilan & 21 June 1990 \\
\hline Manjil-Rudbar (Rasht) & Gilan & 21 June 1990 \\
\hline Manjil-Rudbar (Loushan) & Gilan & 21 June 1990 \\
\hline Lordegan & Chaharmahal and Bakhtiari & 4 March 1992 \\
\hline Golestan & Ardabil & 28 February 1997 \\
\hline Qayen & Khorasan & 10 May 1997 \\
\hline Bam & Kerman & 26 December 2003 \\
\hline Zarand & Kerman & 22 February 2005 \\
\hline Varzaghan & Kerman & 11 August 2012 \\
\hline EMME1 & Mashhad, Khorasan & 2013 \\
\hline EMME2 & Mashhad, Khorasan & 2013 \\
\hline Borazjan & Bushehr & 20 Nov 2017 \\
\hline Sarpol-e-Zahab (Kuick) & Kermanshah & Kermanshah \\
\hline Sarpol-e-Zahab City & & 2017 \\
\hline
\end{tabular}




\begin{tabular}{|c|c|c|c|c|c|c|c|c|c|}
\hline Taxonomy & IM & DS1 & & DS2 & & DS3 & & DS4 & \\
\hline S1H_MRF_H2 & $\begin{array}{l}\mathrm{Sa} \\
(0.6 \\
\mathrm{s})\end{array}$ & -0.6476 & 0.4284 & 0.526 & 0.4283 & 1.0502 & 0.4283 & 1.3771 & 0.4283 \\
\hline S1M_MRF_H2 & $\begin{array}{l}\mathrm{Sa} \\
(0.6 \\
\mathrm{s})\end{array}$ & -0.7884 & 0.4202 & 0.2397 & 0.4202 & 0.7168 & 0.4202 & 1.017 & 0.4202 \\
\hline S1L_MRF_H2 & $\begin{array}{l}\mathrm{Sa} \\
(0.6 \\
\mathrm{s})\end{array}$ & -0.9625 & 0.4181 & -0.0736 & 0.4181 & 0.365 & 0.4181 & 0.6451 & 0.4181 \\
\hline S1H_MRF_H5 & $\begin{array}{l}\mathrm{Sa} \\
(0.6 \\
\mathrm{s})\end{array}$ & -0.4139 & 0.5119 & 0.6604 & 0.512 & 1.1401 & 0.5119 & 1.4392 & 0.5119 \\
\hline S1M_MRF_H5 & $\begin{array}{l}\mathrm{Sa} \\
(0.6 \\
\mathrm{s})\end{array}$ & -0.5534 & 0.5027 & 0.4494 & 0.5027 & 0.9147 & 0.5027 & 1.2074 & 0.5027 \\
\hline S1L_MRF_H5 & $\begin{array}{l}\mathrm{Sa} \\
(0.6 \\
\mathrm{s})\end{array}$ & -0.7085 & 0.5072 & 0.1793 & 0.5072 & 0.6172 & 0.5072 & 0.8967 & 0.5073 \\
\hline S1H_MRF_H8 & $\begin{array}{l}\mathrm{Sa} \\
(1.0 \\
\mathrm{s})\end{array}$ & -0.7811 & 0.4596 & 0.3313 & 0.4596 & 0.8279 & 0.4596 & 1.1375 & 0.4596 \\
\hline S1M_MRF_H8 & $\begin{array}{l}\text { Sa } \\
(1.0 \\
\text { s) }\end{array}$ & -0.9093 & 0.4677 & 0.127 & 0.4676 & 0.608 & 0.4676 & 0.9107 & 0.4677 \\
\hline S1L_MRF_H8 & $\begin{array}{l}\mathrm{Sa} \\
(1.0 \\
\mathrm{s})\end{array}$ & -1.065 & 0.4728 & -0.1484 & 0.4728 & 0.3036 & 0.4728 & 0.5922 & 0.4729 \\
\hline $\begin{array}{l}\text { S3L_MRF\&CSW_- } \\
\text { H5 }\end{array}$ & $\begin{array}{l}\mathrm{Sa} \\
(0.6 \\
\mathrm{s})\end{array}$ & -0.9074 & 0.4015 & -0.0834 & 0.4015 & 0.3417 & 0.4016 & 0.6164 & 0.4016 \\
\hline $\begin{array}{l}\text { S3M_MRF\&CSW_ } \\
\text { H5 }\end{array}$ & $\begin{array}{l}\mathrm{Sa} \\
(0.6 \\
\mathrm{s})\end{array}$ & -0.4205 & 0.4022 & 0.3038 & 0.4023 & 0.7285 & 0.4022 & 1.014 & 0.4023 \\
\hline $\begin{array}{l}\text { S3H_MRF\&CSW_ } \\
\text { H5 }\end{array}$ & $\begin{array}{l}\mathrm{Sa} \\
(0.6 \\
\mathrm{s})\end{array}$ & -0.0325 & 0.4115 & 0.6177 & 0.4115 & 1.0288 & 0.4116 & 1.3124 & 0.4115 \\
\hline $\begin{array}{l}\text { S3L_MRF\&CSW_ } \\
\text { H8 }\end{array}$ & $\begin{array}{l}\mathrm{Sa} \\
(0.6 \\
\mathrm{s})\end{array}$ & -0.804 & 0.4223 & 0.0315 & 0.4224 & 0.4628 & 0.4223 & 0.7415 & 0.4223 \\
\hline $\begin{array}{l}\text { S3M_MRF\&CSW_ } \\
\text { H8 }\end{array}$ & $\begin{array}{l}\mathrm{Sa} \\
(0.6 \\
\mathrm{s})\end{array}$ & -0.3598 & 0.3959 & 0.3065 & 0.3958 & 0.6973 & 0.3959 & 0.96 & 0.3958 \\
\hline $\begin{array}{l}\text { S3H_MRF\&CSW_ } \\
\mathrm{H} 8\end{array}$ & $\begin{array}{l}\mathrm{Sa} \\
\text { (0.6 } \\
\text { s) }\end{array}$ & -0.0303 & 0.3822 & 0.5622 & 0.3822 & 0.9369 & 0.3822 & 1.1953 & 0.3823 \\
\hline
\end{tabular}




\begin{tabular}{|c|c|c|c|c|c|c|c|c|c|}
\hline S4L_SBR_H2 & $\begin{array}{l}\mathrm{Sa} \\
(0.3 \mathrm{~s})\end{array}$ & 0.2654 & 0.4433 & 0.8776 & 0.4433 & 1.2687 & 0.4433 & 1.5395 & 0.2654 \\
\hline S4M_SBR_H2 & $\begin{array}{l}\mathrm{Sa} \\
(0.3 \mathrm{~s})\end{array}$ & 0.3278 & 0.4441 & 1.0968 & 0.4441 & 1.5455 & 0.4441 & 1.8466 & 0.4433 \\
\hline S4H_SBR_H2 & $\begin{array}{l}\mathrm{Sa} \\
(0.3 \\
\mathrm{s})\end{array}$ & 0.3762 & 0.4237 & 1.2422 & 0.4237 & 1.7144 & 0.4237 & 2.0245 & 0.444 \\
\hline S4L_SBR_H5 & $\begin{array}{l}\mathrm{Sa} \\
(0.6 \\
\mathrm{s})\end{array}$ & -0.2863 & 0.4305 & 0.2587 & 0.4305 & 0.6067 & 0.4305 & 0.8476 & 0.4305 \\
\hline S4M_SBR_H5 & $\begin{array}{l}\mathrm{Sa} \\
(0.6 \\
\mathrm{s})\end{array}$ & -0.2287 & 0.4253 & 0.4484 & 0.4253 & 0.8434 & 0.4253 & 1.1084 & 0.4253 \\
\hline S4H_SBR_H5 & $\begin{array}{l}\mathrm{Sa} \\
(0.6 \\
\mathrm{s})\end{array}$ & -0.1804 & 0.4275 & 0.6092 & 0.4274 & 1.0399 & 0.4274 & 1.3229 & 0.4274 \\
\hline S4L_SBR_H8 & $\begin{array}{l}\mathrm{Sa} \\
(1.0 \\
\mathrm{s})\end{array}$ & -0.6772 & 0.3807 & -0.1305 & 0.3807 & 0.2185 & 0.3807 & 0.4601 & 0.3807 \\
\hline S4M_SBR_H8 & $\begin{array}{l}\mathrm{Sa} \\
(1.0 \\
\mathrm{s})\end{array}$ & -0.614 & 0.3837 & 0.0705 & 0.3837 & 0.4698 & 0.3836 & 0.7376 & 0.3836 \\
\hline S4H_SBR_H8 & $\begin{array}{l}\mathrm{Sa} \\
(1.0 \\
\mathrm{s})\end{array}$ & -0.5584 & 0.377 & 0.2303 & 0.377 & 0.6606 & 0.377 & 0.9432 & 0.377 \\
\hline S5L_DUAL_H2 & $\begin{array}{l}\mathrm{Sa} \\
(0.3 \\
\mathrm{s})\end{array}$ & 0.4872 & 0.4286 & 0.9546 & 0.4286 & 1.2891 & 0.4287 & 1.5316 & 0.4287 \\
\hline S5M_DUAL_H2 & $\begin{array}{l}\mathrm{Sa} \\
(0.3 \\
\mathrm{s})\end{array}$ & 0.5288 & 0.4201 & 1.0833 & 0.4201 & 1.4561 & 0.4201 & 1.7194 & 0.4201 \\
\hline S5H_DUAL_H2 & $\begin{array}{l}\mathrm{Sa} \\
(0.3 \\
\mathrm{s})\end{array}$ & 0.6044 & 0.4368 & 1.2479 & 0.4369 & 1.6596 & 0.4368 & 1.945 & 0.4368 \\
\hline S5L_DUAL_H5 & $\begin{array}{l}\mathrm{Sa} \\
(0.6 \\
\mathrm{s})\end{array}$ & -0.1129 & 0.4104 & 0.2895 & 0.4104 & 0.5776 & 0.4103 & 0.7864 & 0.4104 \\
\hline S5M_DUAL_H5 & $\begin{array}{l}\mathrm{Sa} \\
(0.6 \\
\mathrm{s})\end{array}$ & -0.0581 & 0.405 & 0.426 & 0.405 & 0.7513 & 0.405 & 0.9811 & 0.405 \\
\hline S5H_DUAL_H5 & $\begin{array}{l}\mathrm{Sa} \\
(0.6 \\
\mathrm{s})\end{array}$ & 0.0095 & 0.4015 & 0.5767 & 0.4015 & 0.9395 & 0.4015 & 1.1909 & 0.4015 \\
\hline S5L_DUAL_H8 & $\begin{array}{l}\mathrm{Sa} \\
(1.0 \\
\mathrm{s})\end{array}$ & -0.5102 & 0.3734 & -0.1105 & 0.3733 & 0.1757 & 0.3734 & 0.3831 & 0.3733 \\
\hline S5M_DUAL_H8 & $\begin{array}{l}\mathrm{Sa} \\
(1.0 \\
\mathrm{s})\end{array}$ & -0.4398 & 0.3696 & 0.0496 & 0.3696 & 0.3787 & 0.3696 & 0.6112 & 0.3696 \\
\hline
\end{tabular}




\begin{tabular}{|c|c|c|c|c|c|c|c|c|c|}
\hline S5H_DUAL_H8 & $\begin{array}{l}\text { Sa } \\
(1.0 \\
\text { s) }\end{array}$ & -0.3733 & 0.3649 & 0.1854 & 0.3649 & 0.5428 & 0.3649 & 0.7905 & 0.3648 \\
\hline S6L_SBR_H2 & $\begin{array}{l}\mathrm{Sa} \\
(0.3 \mathrm{~s})\end{array}$ & -0.8171 & 0.3815 & -0.165 & 0.3816 & 0.2049 & 0.3815 & 0.4508 & 0.3816 \\
\hline S6M_SBR_H2 & $\begin{array}{l}\mathrm{Sa} \\
(0.3 \mathrm{~s})\end{array}$ & -0.611 & 0.3907 & 0.0551 & 0.3907 & 0.4378 & 0.3907 & 0.6932 & 0.3908 \\
\hline S6L_SBR_H5 & $\begin{array}{l}\mathrm{Sa} \\
(0.6 \\
\mathrm{s})\end{array}$ & -1.2867 & 0.3843 & -0.6374 & 0.3843 & -0.268 & 0.3843 & -0.0223 & 0.3843 \\
\hline S6M_SBR_H5 & $\begin{array}{l}\mathrm{Sa} \\
(0.6 \\
\mathrm{s})\end{array}$ & -1.0871 & 0.381 & -0.4523 & 0.381 & -0.0867 & 0.381 & 0.1574 & 0.381 \\
\hline WD- $\mathrm{H} 2$ & $\begin{array}{l}\mathrm{Sa} \\
(0.3 \\
\mathrm{s})\end{array}$ & -1.3859 & 0.4488 & -0.299 & 0.4489 & 0.1538 & 0.4489 & 0.4322 & 0.4489 \\
\hline
\end{tabular}

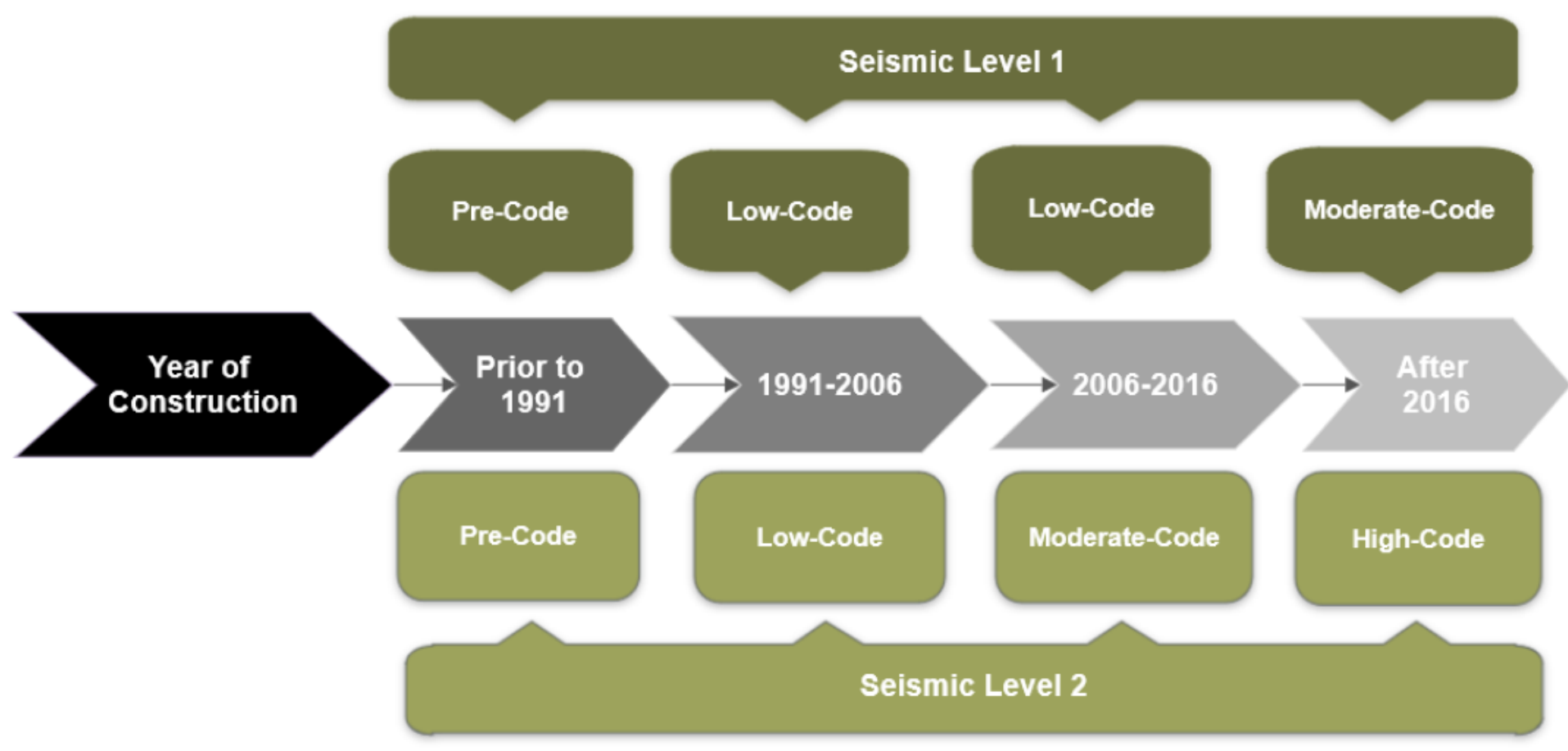

Figure 1

Iranian buildings classification based on code-level 


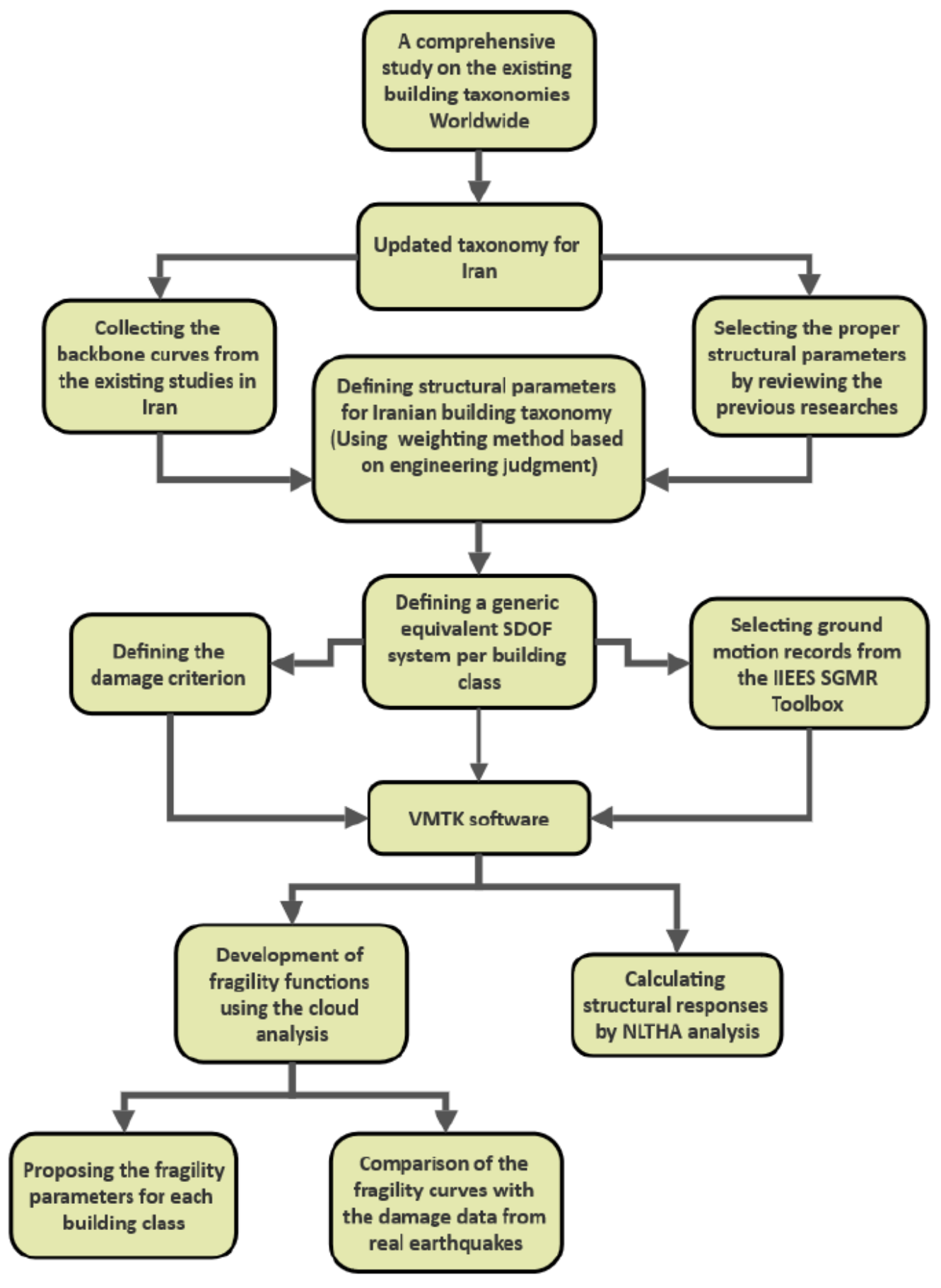

Figure 2

Flowchart of procedures for developing fragility functions 


\section{Image not available with this version}

\section{Figure 3}

This image is not available with this version.

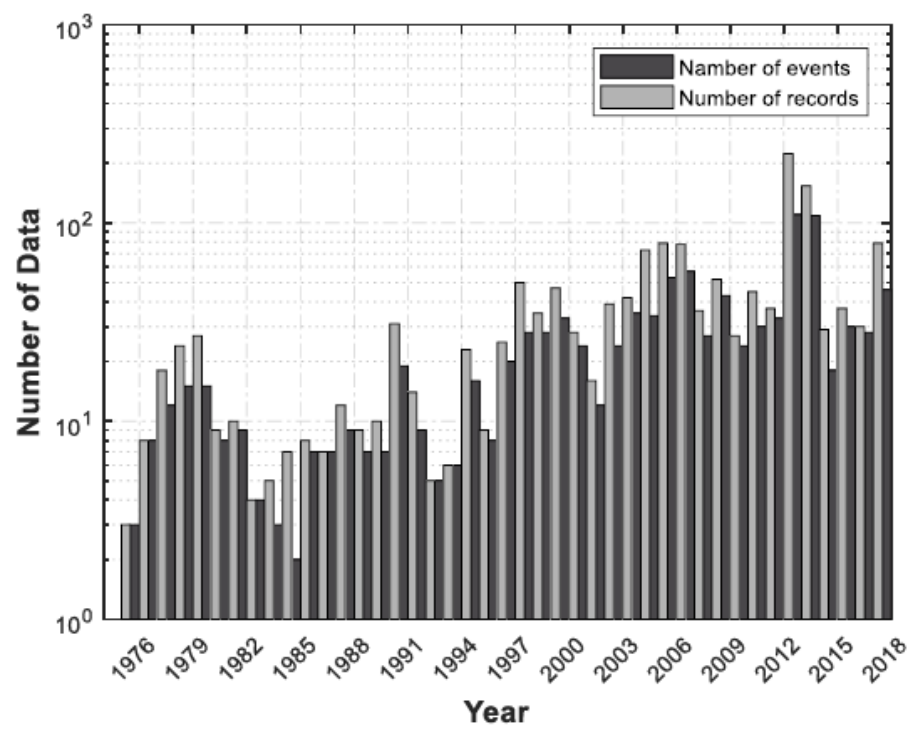

(a)

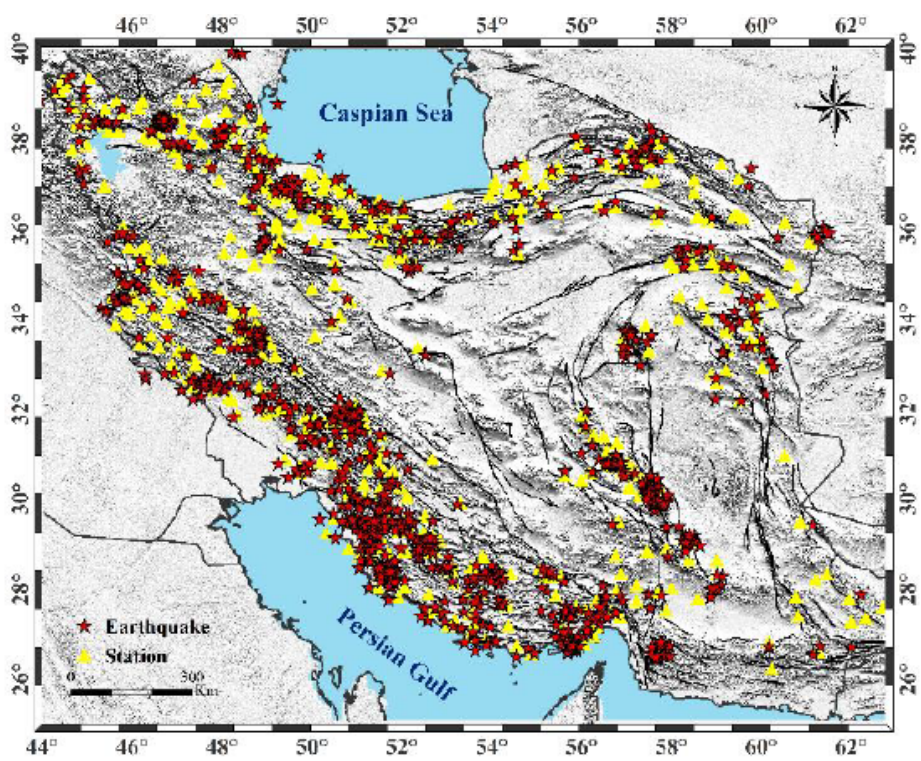

(b)

Figure 4

a) Distribution of number of events and records versus years, b) Locations of the considered stations and selected earthquakes 

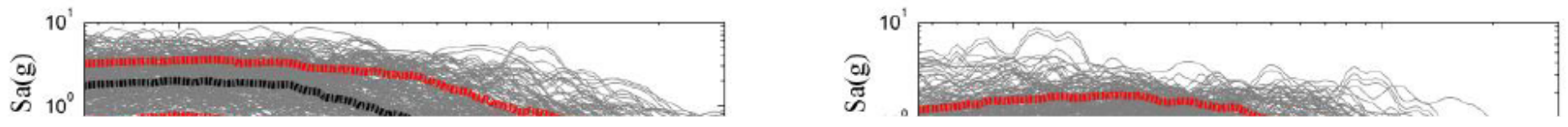

Figure 5

Response spectra of the selected ground motion records considering: a) PGA, b) Sa (0.3s), c) Sa (0.6), and d) Sa (1). 

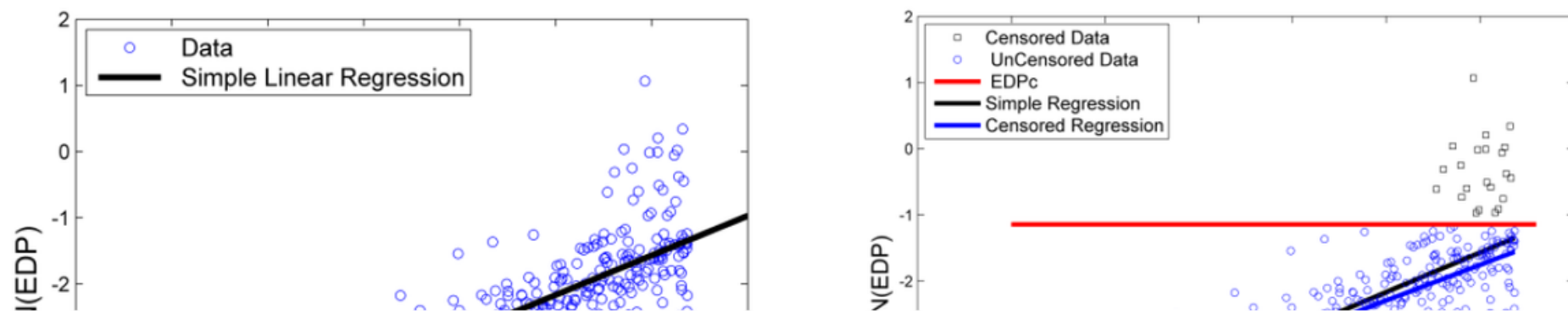

Figure 6

a) Scatter of In (EDP) and In (IM) with Curve Fitting using Linear Regression, b) Scatter of In (EDP) and In (IM), with the associated best-fit uncensored and censored regressions

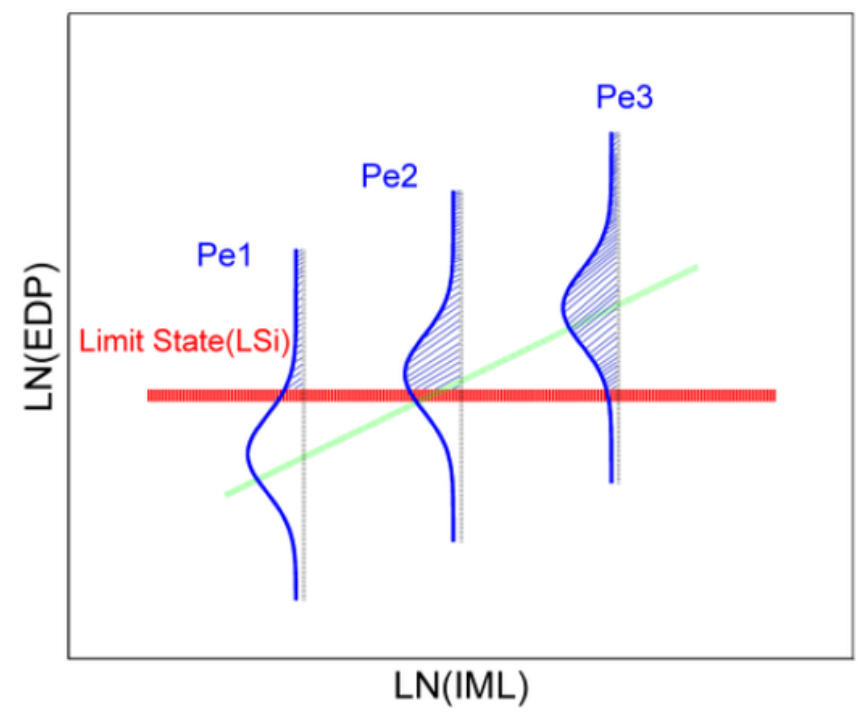

(a)

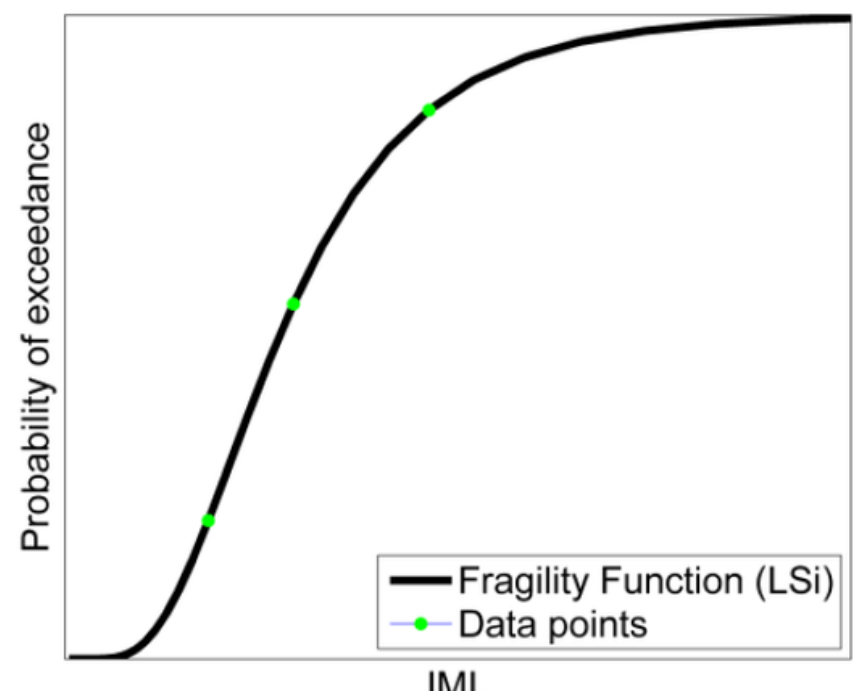

IML

(b)

\section{Figure 7}

A schematic of the fragility assessment based on the cloud analysis approach: (a) Probability of exceedance for three IMLs given a limit State; (b) Fragility function for a given limit State.

\section{Figure 8}



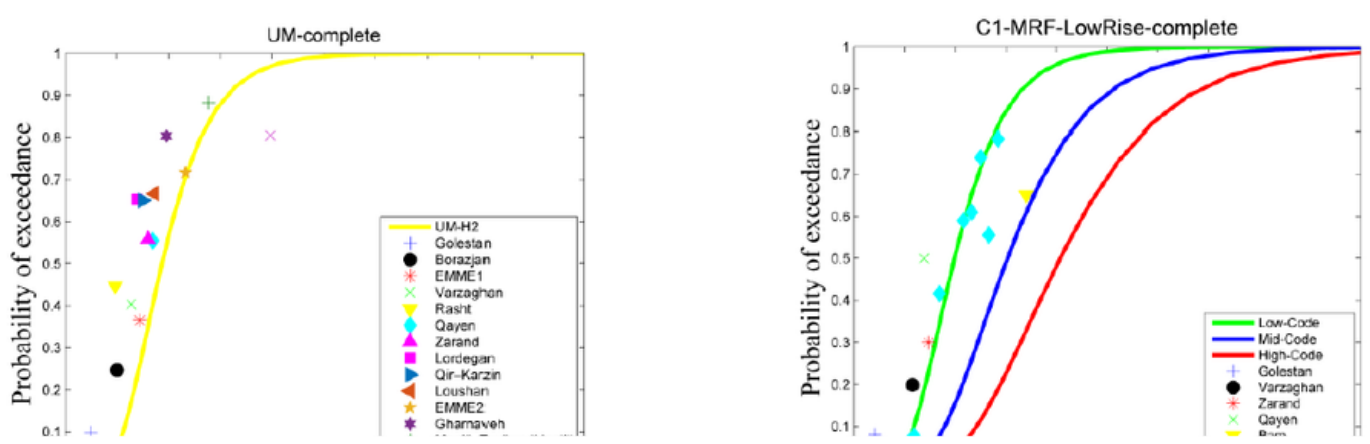

\section{Figure 9}

Comparison of developed fragility function with the damage data from Iran's past earthquakes for (a) unreinforced masonry, (b) low-rise RC moment frame buildings, (c) low-rise Steel moment frame buildings, (d) mid-rise steel braced frame buildings, (e) mid-rise Steel frames with a dual system buildings.

\section{Supplementary Files}

This is a list of supplementary files associated with this preprint. Click to download. 
- Table1.docx

- Table4.docx

- AppendixA.docx

Page 33/33 